\title{
Kültürel Karşılaşmalar: İtalya'daki Lecce Kentinin Barok Mimarisi Üzerindeki Olası Osmanlı Sanatı Etkileri
}

\section{Cultural Encounters: The Probable Effects of Ottoman Art on the Baroque Architecture of the City of Lecce in Italy}

\author{
Aslı Üntak Tarhan ${ }^{1}$ (D)
}

${ }^{1}$ Sorumlu yazar/Corresponding author: Aslı Üntak Tarhan (Doktora Öğrencisi), Mimar Sinan Güzel Sanatlar Üniversitesi, Sanat Tarihi Anabilim Dalı, Batı Sanatı ve Çağdaş Sanat Bölümü, İstanbul, Türkiye

E-posta: asli.untak@gmail.com

ORCID: 0000-0003-4121-1528

Başvuru/Submitted: 12.08 .2019 Revizyon Talebi/Revision Requested: 13.04.2020

Son Revizyon/Last Revision Received: 18.04.2020

Kabul/Accepted: 20.04 .2020

Online Yayın/Published Online: 30.06 .2020

Atıf/Citation: Untak Tarhan, Asli, “Kültüre Karșılaşmalar: İtalya'daki Lecce Kentinin Barok Mimarisi Üzerindeki Olası Osmanlı Sanatı Etkileri". Sanat Tarihi Yıllığı - Journal of Art History 29 (2020), 201-246

https://doi.org/10.26650/sty.2020.010 öz

Güney İtalya'da Puglia Bölgesi'nde bulunan Lecce kenti, tarih boyunca, bulunduğu konum nedeniyle, birçok değişik kültürün etkisi altında kalmıştır. Bu kültürlerden biri, 1480 yılında Osmanlıların, Fatih Sultan Mehmed döneminde, Lecce'ye çok yakın bir kent olan Otranto'yu kuşatıp ele geçirmesiyle birlikte, Türk kültürü olmuştur. Bu etki, Lecce şehrinde, Santa Croce Kilisesi gibi dini yapılarda 16. ve 17. yüzyıla tarihlenen bir kısım heykel ve kabartmalarda Türk imgesinin ele alınması şeklinde kendini göstermiştir. Bu çalışmada öne sürülen nokta, kentte izlerine rastlanan bu Türk imgesinin ötesinde, Türk sanatının doğrudan Lecce'deki mimariyi etkilemiş olabileceğidir. Lecce'ye yaptığımız üç araştırma gezisinde Barok üsluplu dini ve sivil mimari örneklerinden toplanan veriler doğrultusunda gündeme getirilen bu olasılığa, çeşitli yapılardaki süsleme motifleri ve mimari formların, Türk sanatındaki bazı öğelerle karşılaştırılması yoluyla işaret edilmektedir. Söz konusu formlardan birincisi, Lecce'de Barok üsluplu birçok yapıda tespit ettiğimiz ve Türk sanatında sıkça kullanılan palmet motifine benzeyen bezeme öğesidir. Saptadığımız ikinci form, yine aynı dönemdeki Türk sanatında karşımıza çıkan, iki yana uzantıları olan madalyon formu salbekli şemse motifidir. Belirlenen üçüncü form ise, bir sivil mimari örneği olan, 17. yüzyıl yapısı Palazzo dei Celestini'de belgelediğimiz Bursa kemeri benzeri mimari öğedir. Bu benzerliklerden yola çıkarak, Osmanlı ve İtalyan kültürleri arasında bir etkileşime işaret edilmektedir.

Anahtar kelimeler: Lecce kentinin Barok Mimarisi, Türk Süsleme Sanatı, Osmanlı Mimarisi, Palmet, Şemse, Bursa kemeri, Kültürel karşılaşmalar

\section{ABSTRACT}

The city of Lecce has been impacted by various cultures. One of these has been the Turkish culture, as a consequence of the Ottomans'besieging and taking hold of the city of Otranto, which was very close to Lecce, in 1480 during the reign of Fatih Sultan Mehmed. This impact manifested itself in Lecce in the handling of the Turkish image on sculptures and reliefs that date back to the 16th and 17 th centuries in the Church of Santa Croce. The point put forth in this study is that Turkish art might have directly affected the architecture in Lecce. This possibility is pointed out through comparing the motifs of ornamentation in 
various buildings in Lecce with elements in Turkish art. The first form is the ornamentation found in Baroque buildings in Lecce, which resembles the palmette motif in Turkish art. The second form is the medallion with extensions to both sides (salbekli şemse in Turkish), which is again encountered in Turkish art. The third form is the architectural element reminiscent of the Bursa arch, that was located in the Baroque structure Palazzo dei Celestini. These similarities suggest an encounter between Ottoman and Italian cultures.

Keywords: The Baroque Architecture of Lecce, Turkish Art of Ornamentation, Ottoman Architecture, Palmette, Medallion, Bursa arch, Cultural encounters 
İtalya'nın en güneyinde, topuk kısmında, Puglia Bölgesi'nde yer alan Lecce kenti, coğrafi konumu sebebiyle, çok değişik kültürlerin etkisi altında kalmıştır (F.1). Paleolitik çağdan beri içinde yerleşim barındıran bu alanda, M.Ö. 15. yüzyıl - 12. yüzyıl arasında, Yunanistan'ın Mikene şehrinden gelen bir grup, koloniler kurmuştur. Hem bu koloniler, hem de M.Ö. 8. yüzyılda, yine Yunanistan'ın Sparta ve Laconia bölgelerinden gelen ve Puglia'nın batı kısmına yerleşip Magna Grecia adı verilen uygarlığın kökenlerini oluşturan koloniler, Antik çağda bu coğrafyada, Yunan sanatı etkileri oluşturmuştur. ${ }^{1}$ Lecce şehri, Ortaçağ' da ise, içinde bulunduğu Puglia Bölgesi'nde yerleşimler kuran Bizans ve Arap kültürleri ile ilişki içinde olmuştur. Özellikle, şehirdeki Barok mimaride, 1şık-gölge karşıtlığını ön plana çıkaran, arabesk ve geometrik motiflerin kullanıldığı bezemeci anlayış, İslam sanatından izler taşımaktadır. ${ }^{2} 11$. yüzyılda, Normanların Güney İtalya'yı işgal etmeleri ile birlikte, Lecce'de Norman varlığı da söz konusu olmuş ve Normanlar, burada inşa ettikleri yapılarla, kente kendi mimari estetik anlayışlarını getirmişlerdir. ${ }^{3}$

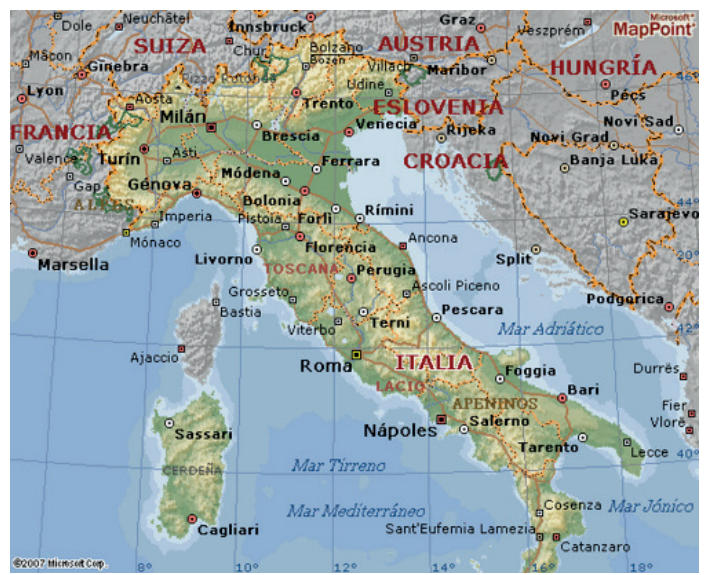

F. 1: İtalya Haritasinda Lecce'nin Konumu

(https://santificarnos.com/ciudades-de-argentina-mendoza-travel.html, 02.03.2019)

Kenti etkileyen başka bir kaynak, Türk kültürü olmuştur. Lecce’nin de içinde bulunduğu Salento Bölgesi, Fatih Sultan Mehmed (1432-1481) döneminde, Türk akınlarına maruz kalmıştır. Yine bu bölgede bulunan ve Lecce'ye coğrafi konum olarak çok yakın olan Otranto, 1480 yılında Osmanlılar tarafından ele geçirilmiştir. 16. yüzyılda Lecce kentinde birçok iz bırakan yönetici İspanya Kralı ve Kutsal Roma İmparatoru V. Carlo (1500-1558), bölgede beliren Türk tehdidine karşı önlem almak amacıyla, 1539-49 yılları arasında, Salentino'lu

1 Francesco Radino, "La Puglia dalla civiltà messapica all'autonomia regionale", Puglia, Touring Club Italiano, 1986, s. 277.

2 Maurizio Calvesi, Mario Manieri-Elia, Architettura Barocca a Lecce e in terra di Puglia, Carlo Bestetti Edizioni d'Arte, Roma, 1971, s. 25-27.

3 Marcello Fagiolo, Vincenzo Cazzato, La città nella storia d'Italia: Lecce, Editori Laterza, Bari, 1984, s. 24-25. 
mimar Gian Giacomo dell'Acaya'ya (1500-1570), şehirde bulunan eski bir Norman kalesinin üzerine, elmas formlu burçları olan devasa bir kale yaptırmıştır. Bunun yanı sıra, yine aynı amaçla, şehri surlarla çevirmiştir (F.2). ${ }^{4}$

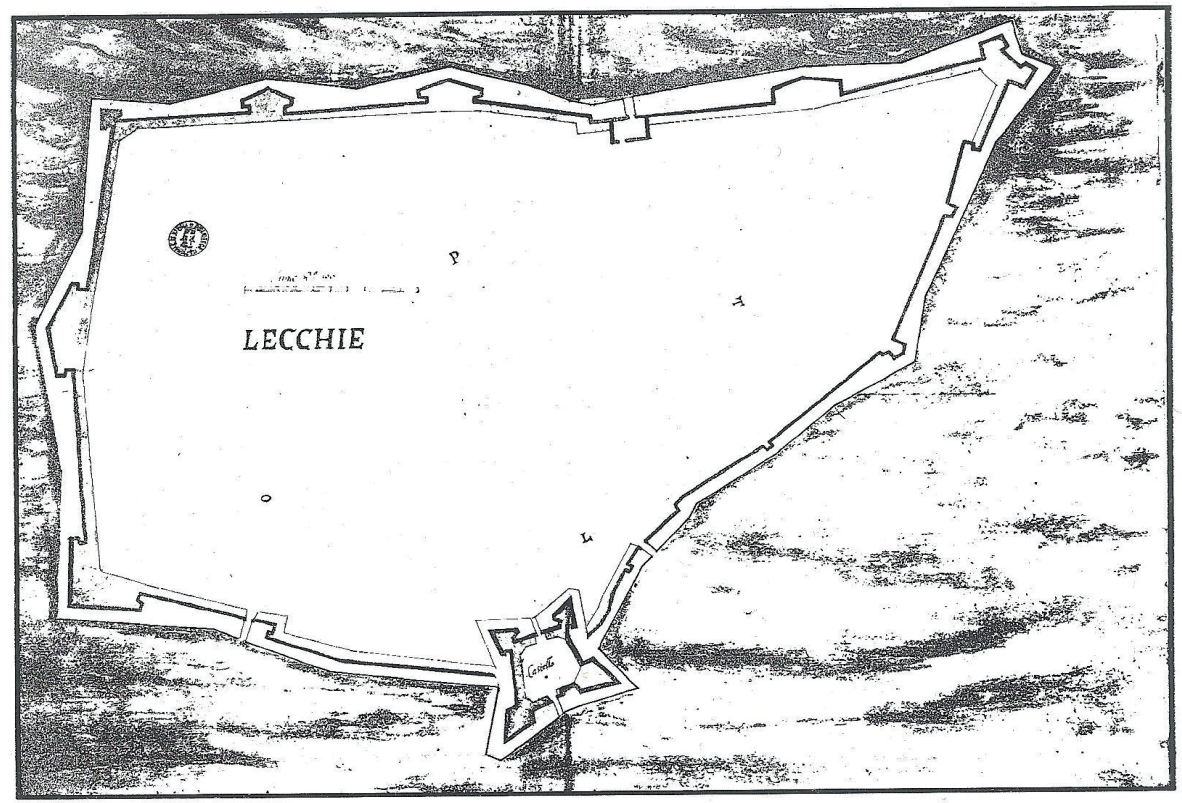

F. 2: V. Carlo döneminde Lecce kentinde yapılmış olan kale ve surlar (Congedo, 1995, s. 16)

1571 yılında Osmanlı Devleti ile Haçlı Donanması arasında gerçekleşen (ve ismi Batı kaynaklarında "Lepanto" olarak geçen) İnebahtı Deniz Savaşı da, şehrin hafızasında önemli bir yere sahip olmuştur. Haçlı Donanması'nın Osmanlı Donanması karşısında kazandığı zaferin izlerini, şehrin en büyük kilisesi olan Santa Croce Kilisesi’nin (F.3) cephe tasarımında görmek mümkündür. ${ }^{5}$ Yapımına 1548 yılında başlanan kilisenin, tasarımı mimar Gabriele Riccardi'ye (1524-82) ait olan giriş katı, üstlerindeki korkuluğu taşıyormuş izlenimi veren insan ve hayvan şeklindeki atlant adı verilen heykellerle sonlanmaktadır. ${ }^{6}$ Celestin Tarikatı için inşa edilmiş olan ${ }^{7}$ ve 1571 'de İnebahtı (Lepanto) Savaşı'nda Hıristiyanların Osmanlılara karşı kazandığ 1 zafere adanan ${ }^{8}$ kilisenin, Romanesk ve Gotik gibi Ortaçağ mimarisine ait bazı üslupların etkilerini (gül pencere kullanımı gibi) taşıyan giriş katını boydan boya kat

4 Desmond Seward, Susan Mountgarret, Old Puglia: A Cultural Companion to South-Eastern Italy, Haus Publishing, İspanya, 2016, s. 15.

5 Calvesi, Manieri-Elia, a.g.e., s. 25-27.

6 Michele Paone, Lecce: Elegia del Barocco, Congedo Editore, Lecce, 1979, s. 148.

7 Calvesi, Manieri-Elia, a.g.e., s. 16.

8 Guida Artistica d'Italia, Arnoldo Mondadori Editore, Cilt 3, Milano, 1978, s. 590.

9 Michele Paone, Chiese di Lecce, Cilt 1, Congedo Editore, Lecce, 1978. 
eden frizin üzerinde diz çökmüş vaziyette bulunan bu on üç atlant, kilisenin dış cephesinin tasarımına ait olan en önemli unsurlardandır.

Söz konusu heykellerin arasında, aslan, kartal, ejderha gibi canavarlık, vahşilik ve gaddarlık sembolleri (F.4-5), Roma'nın kuruluş efsanesine göre ikizlerini emziren dişi kurt (F.6) ve Nemea aslanının derisiyle Herkül (F.7) gibi pagan dünyaya ait simgeler yer almaktadır. Bütün bu sembollerin arasında, kilisenin 1582 yılına tarihlenen bu kısmında, yakın bir zamanda (1571'de İnebahtı Savaşı'nda) Haçlı Donanması tarafından yenilgiye uğratılmış bir Türk askeri de bulunmaktadır (F.8). Buradaki sembolizm, Hıristiyanlığın, tüm vahşilik, kötülük simgelerine ve o dönem için "antik ve modern kafirler" olarak tasavvur edilmiş olan Paganlar ve Müslümanlara boyun eğdirmesidir. ${ }^{10}$ Başka bir deyişle, cephenin bu bölümündeki simgesel anlam, Hıristiyanlığın, kendi karşısında bulunan bütün "canavarlara" (Pagan veya diğer unsurları barındıran düşman dünya) diz çöktürmesidir. ${ }^{11}$

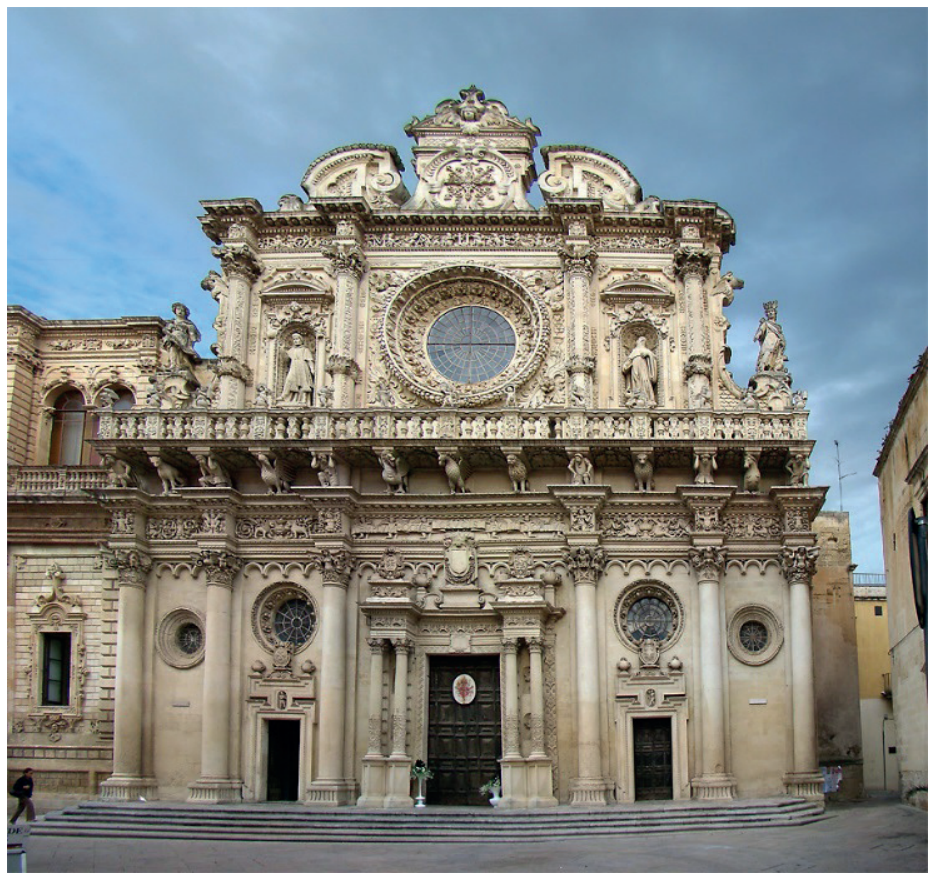

F. 3: Lecce, Santa Croce Kilisesi, ön cephe

10 Calvesi, Manieri-Elia, a.g.e., s. 16.

11 Fagiolo, Cazzato, a.g.e., s. 7. 


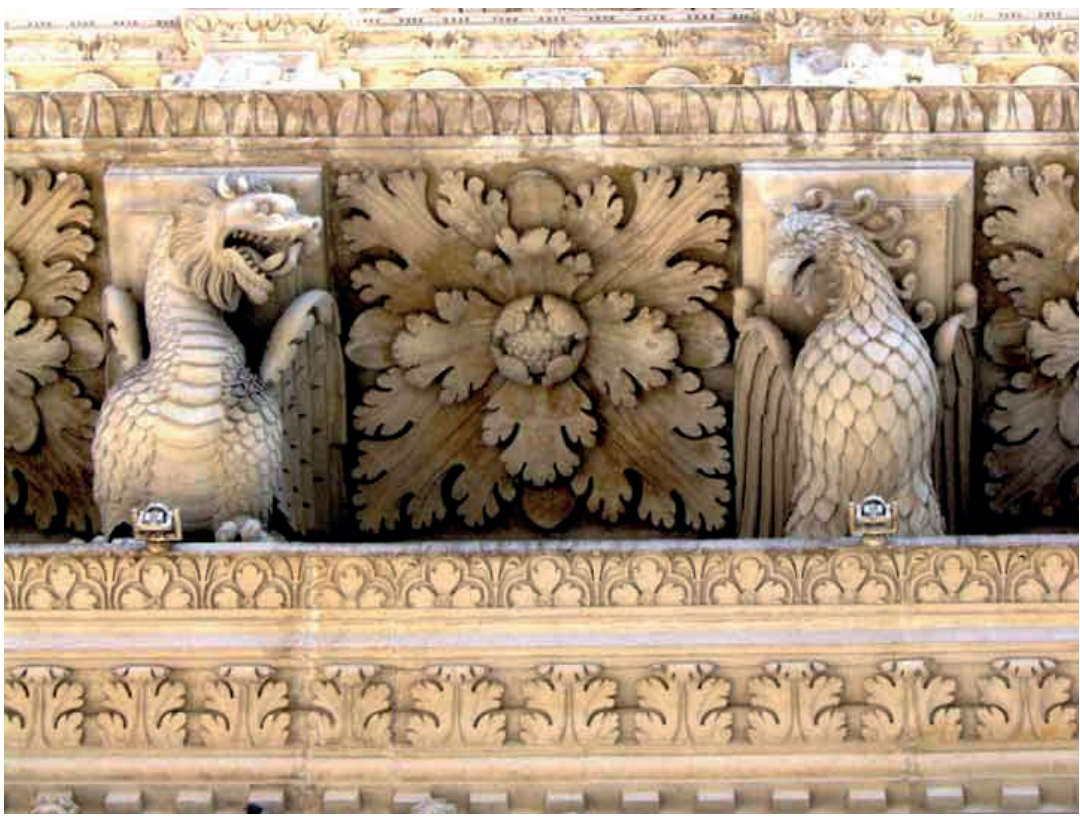

F. 4: Lecce, Santa Croce Kilisesi, ayrınt1

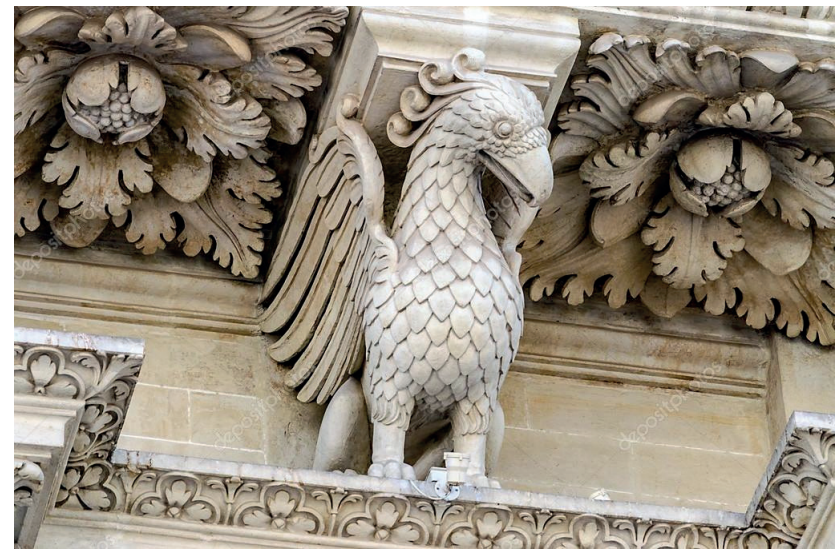

F. 5: Lecce, Santa Croce Kilisesi, ayrıntı 


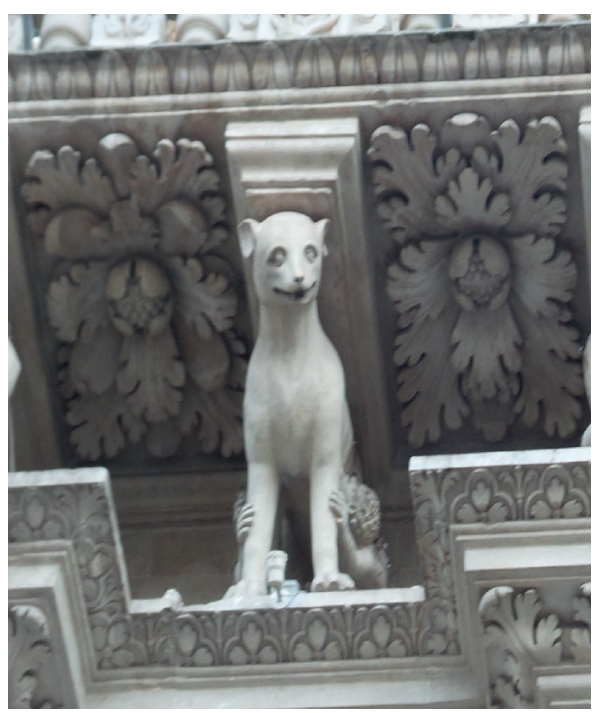

F. 6: Lecce, Santa Croce Kilisesi, ayrıntı
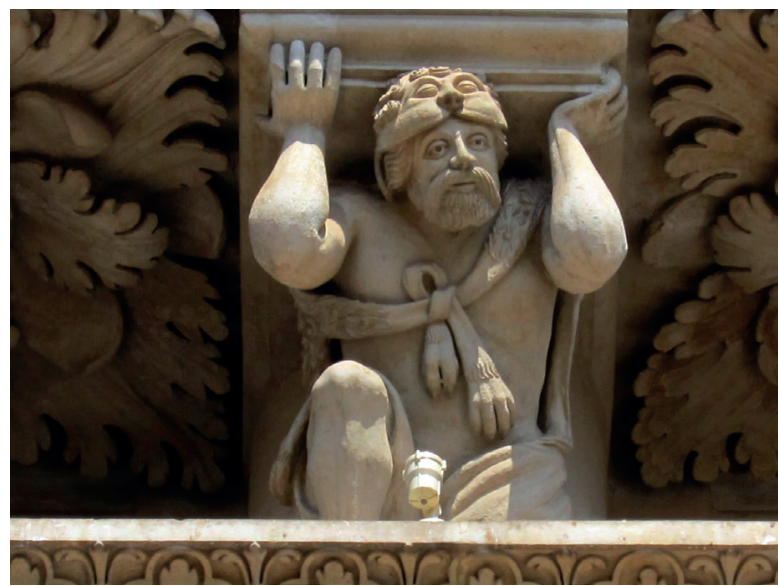

F. 7: Lecce, Santa Croce Kilisesi, ayrınt1 


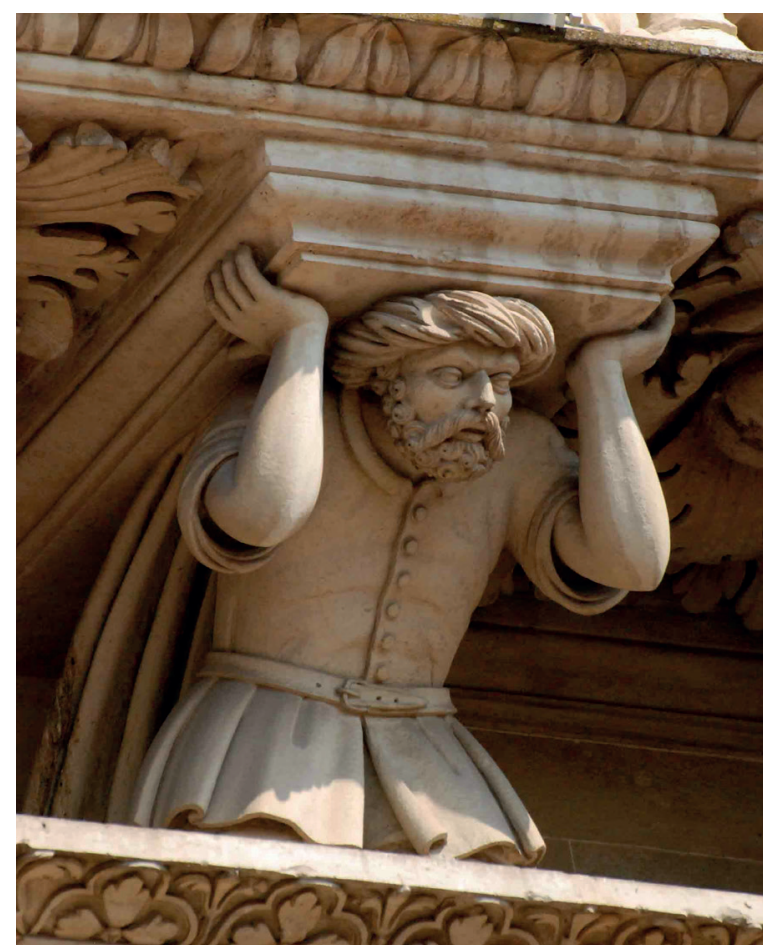

F. 8: Lecce, Santa Croce Kilisesi, ayrınt1

Mimaride böyle bir sembolik anlamın kullanılmasına ilişkin bilgi, M.Ö. 1. yüzyılda yaşamış olan mimar ve yazar Vitruvius’un Mimarlık Üzerine On Kitap ("De Architectura Libri Decem") adlı eserinin birinci kitabında yer bulmaktadır. ${ }^{12}$ Vitruvius, bu konuyla ilgili şu ifadeleri kullanmaktadır:

[...] Karyatid adı verilen uzun giysili kadınların mermer heykellerini sütun yerine kullandığını ve pervaz (korona) ile damlalıkları (mutule) kadınların başı üzerine yerleştirdiğini düşünürsek, mimar soranlara şu açıklamayı yapacaktır: Peloponnes yarımadasında bir kent devleti olan Karya, Yunanistan'a karşı Perslerin tarafını tutmuştu; daha sonra savaşta zaferle özgürlüklerini kazanan Yunanlılar, seferberlik ilan edip Karya halkına savaş açtılar. Kenti ele geçirerek erkekleri öldürdüler ve devleti ıssızlığa terkettiler; kadınları da köle olarak kaçırdılar. Ancak uzun giysilerini ve diğer evlilik simgelerini çıkarmalarına izin vermeyerek zafer alayında onları zorla teşhir ettiler. Bu kadınlar utançlarının ağırlı̆̆ı altında ezilerek sonsuza dek köleliği temsil ettiler ve devletlerinin kefaretini ödediler. Böylece dönemin mimarları, Karya halkının günah ve cezaların ardılları tarafından da bilinerek sürdürülmesi için kamu yapılarına yük taşıdıkları görülecek biçimde bu kadınların heykellerini yerleştirdiler.

12 Bu bağlantıya, Prof. Dr. Nilüfer Öndin tarafından işaret edilmiştir. 
[...] Aynı şekilde, Lakedaimonyalılar Agesipolis'in oğlu Pausanias'ın önderliğinde çok ufak bir kuvvetle uçsuz bucaksız Pers ordusunu Palataea Savaşı'nda yendikleri zaman yağma ve ganimetlerle görkemli bir zafer alayı düzenlediler; satıştan elde ettikleri paralarla da halklarının ününe ve kahramanlığına adanan bir zafer andacı olan Pers Sundurması'nı inşa ettiler. Buraya barbar giysileri ile çatıyı taşıyan ve hakettikleri bu aşağılama ile gururu çiğnenmiş tutsakların heykellerini yerleştirdiler. Böylelikle düşmanlar, Lakedaimonyalıların cesareti önünde korkudan titreyecekler, kendileri ise kahramanlıklarının görkeminden cesaret alarak özgürlüklerini savunmaya hazır olacaklardı. O zamandan sonra, bir çokları, saçaklık ve süslemelerini taşıyan Pers heykellerini kullanarak yapıtlarının çeşitliliğini arttırdılar. ${ }^{13}$

Vitruvius'un belirttiği gibi, üzerinde egemenlik kurulan halktan kişilerin heykellerinin, mimaride, bir saçaklığ 1 ya da bir sundurmayı taşıyorlarmışçasına betimlenmeleri, tutsak edilmiş ya da yenilgiye uğratılmış olanlar için bir aşağılanma ve gurur kırma ifadesi şeklinde; zafer kazanan taraf için ise, kendi kahramanlıklarının bir teşhiri olarak yer almaktadır. Antik Yunan’da, M.Ö. 421-405 yılları arasında Atina Akropolis’inde inşa edilmiş olan Erechtheion Tapınağı'nda, ${ }^{14}$ üzerlerindeki kirişi taşır vaziyette görülen ve karyatid adı verilen kadın heykeli biçimindeki sütunlar, bunun güzel örneklerinden biridir (F.9). Buna benzer bir sembolizmi yansitan heykel tipleri, Vitruvius'un eserinin Avrupa'nın değişik yerlerinde basılmış olan çeşitli versiyonlarında tasvir edilmişlerdir. ${ }^{15}$ Bu versiyonlardan, İtalyan mimarlık tarihçisi Mario Manieri Elia’nın (1929-2011) Lecce Santa Croce Kilisesi'nin cephe tasarımı ile olan ilişkisi bağlamında işaret ettiği, İtalyan mimar Cesare Cesariano ${ }^{16}$ (1476/78-1543) tarafından İtalyanca'ya çevirilip 1521 'de basılmış olanı, yukarıda bahsedilmiş olan, aralarında Osmanlı askerinin de bulunduğu diz çökmüş heykellerin ifade ettiği anlamı anlamak açısından önem taşımaktadır.

13 Vitruvius, Mimarlık Üzerine On Kitap, Çev. Suna Güven, Şevki Vanlı Mimarlık Vakfı Yayınları, 2013, s. 5-6.

14 David Watkin, A History of Western Architecture, Lauernce King, Slovenya, 1996, s. 26.

15 Watkin, a.g.e., s. 6.

16 Cesare Cesariano (1476/78-1543), özellikle Kuzey İtalya'da çalışmış ve bu bölgenin mimarisinden etkilenmiş bir mimardır. Milano kenti, hayatının ve çalışmalarının odağı olmuştur. Milano dışında, Ferrara, Reggio Emilia ve Parma'da da faaliyet göstermiştir. Cesariano'nun, 1521 yılında Gottardo da Ponte tarafindan Como'da basılmış olan Vitruvius'un "Mimarlık Üzerine On Kitap" (De Architectura Libri Decem) çevirisi, bu metnin Latince'den İtalyanca'ya yapılmış olan ilk tam tercümesi olma özelliğini taşımaktadır (Bkz. Christof Thoenes, Bernd Evers, Architectural Theory: From the Renaissance to the Present, Taschen, 2011, s. 66). 


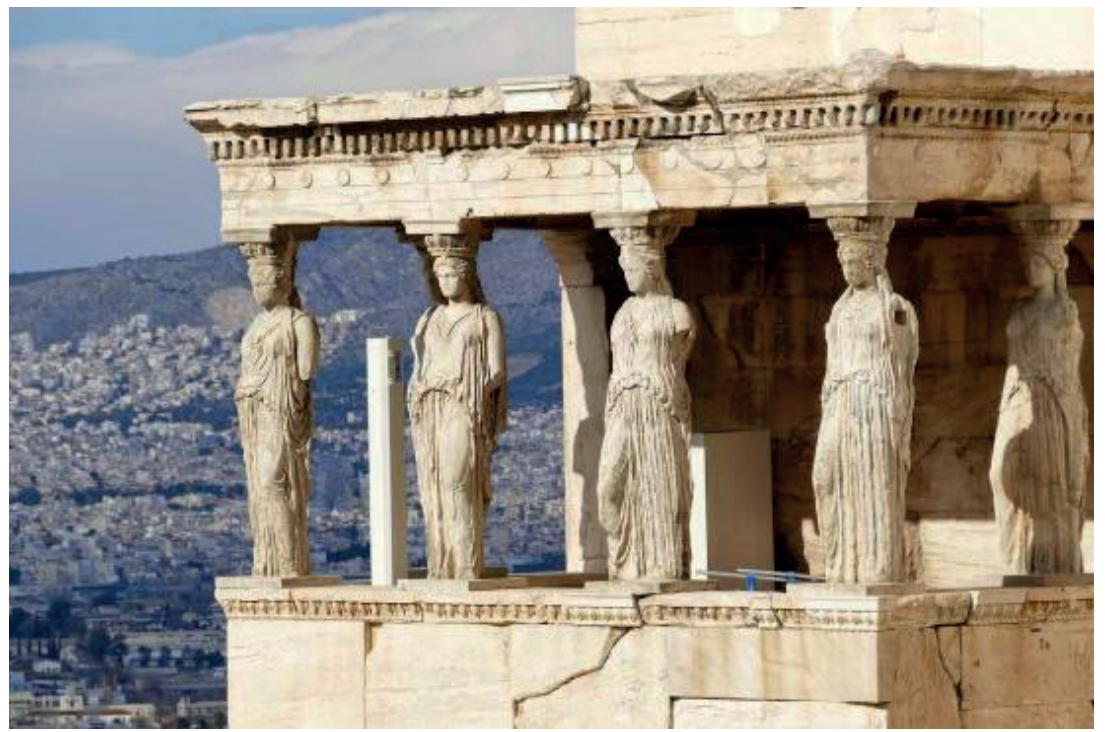

F. 9: Atina, Akropolis, Erechtheion Tapınağ

(https://tr.123rf.com/photo_29243333_erechtheion-atina-yunanistan-kad\%C4\%B1nheykelleri.html, 02.05.2019)

Manieri Elia, Vitruvius’un eserinin Cesariano çevirisi baskısının, Kuzey İtalya’da Lombardiya Bölgesi’nde iyi bilindiğini belirtmekte ve Güney İtalya’ya da ulaşmış olabileceği yönünde tahmin yürütmektedir. Yazar, Santa Croce Kilisesi'ni inşa ettiren Celestin Tarikatı gibi eğitime büyük önem veren bir dini oluşumun, bu Vitruvius edisyonunu bir şekilde elde etmiş olabileceğine ve kilisenin birinci katının tasarımından sorumlu olan mimar Gabriele Riccardi'nin de buradaki çizimleri görme ihtimaline işaret etmektedir. Manieri Elia'ya göre, Cesariano'ya ait tercümenin baskısının Porticus Persica ("Pers Sundurması") (Liber I, VII recto: Birinci Kitap, Yedinci Ön Yüz) sayfasındaki Pers savaş tutsaklarının tasvirleriyle, Santa Croce Kilisesi'nin cephesinde, diz çökmüş bir şekilde, üstlerindeki korkuluğu taşıyormuş gibi yerleştirilmiş heykellerin betimlenme şekilleri arasındaki benzerlik aşikardır. ${ }^{17}$ Gerçekten de, kilisenin cephesindeki, aralarında Türk askerinin de bulunduğu insan formlu heykeller $(\mathbf{F . 8 , 1 0})$ ve Cesariano'nun Vitruvius çevirisinin 1521 yılı baskısının söz konusu sayfasında (F.11), diz çökmüş bir şekilde üstlerindeki saçaklığı taşıyormuş gibi resmedilmiş Pers köleleri arasındaki bağ dikkat çekicidir. Heykelleri tasarlayan mimar Riccardi'nin bu sayfadaki tasvirleri görüp, Hıristiyan dünyası tarafından yenilgiye uğratıldığı düşünülen çeşitli unsurları (Pagan, Müslüman) aşağılama amacıyla, benzer bir şekilde ele almış olması muhtemeldir.

17 Mario Manieri Elia, Barocco Leccese, Electa, Milano, 1996, s. 76-77. 


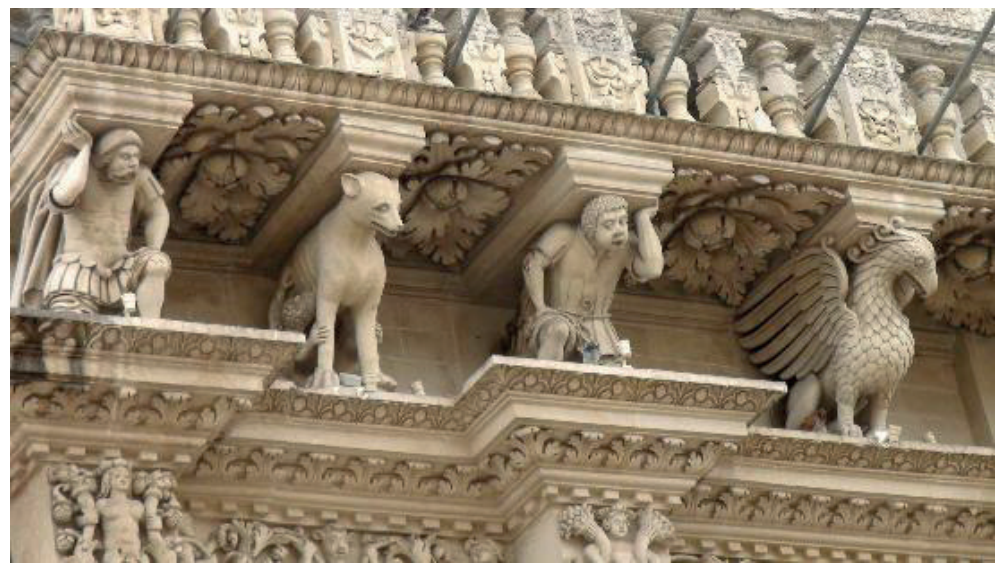

F. 10: Lecce, Santa Croce Kilisesi, ayrıntı

LIBER

PRIMVS

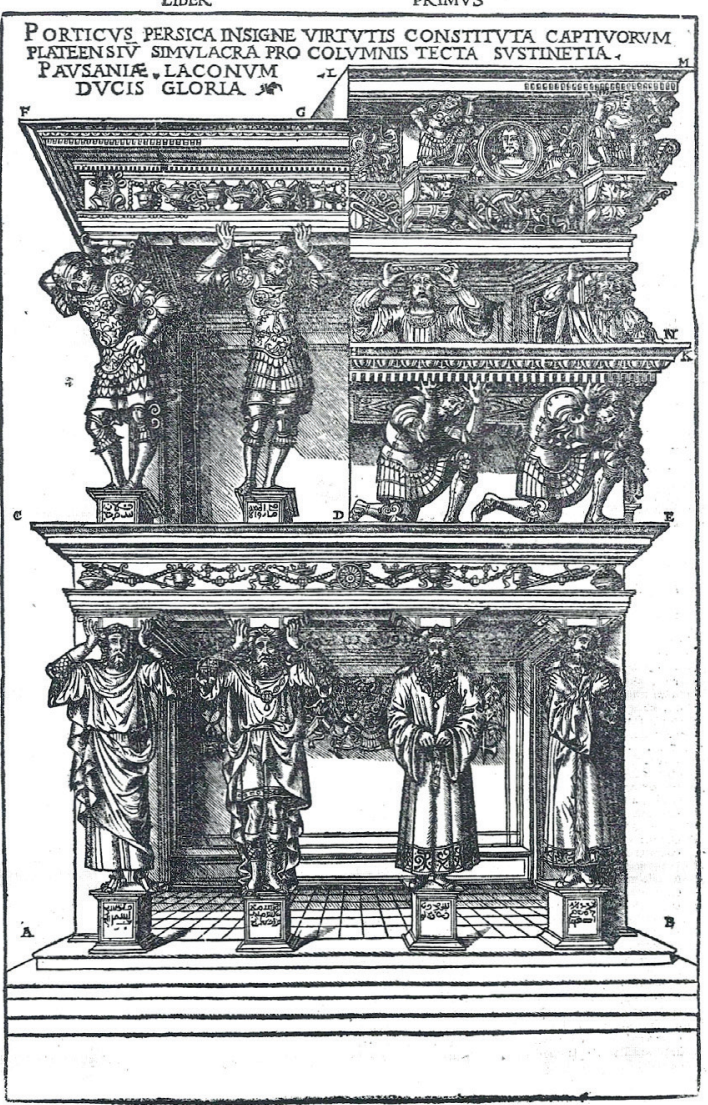

F. 11: Vitruvius'un eserinin Cesariano'ya ait tercümesinin baskısından bir sayfa, Birinci Kitap, Yedinci Ön Yüz, 1521 (Manieri Elia, 1996, s. 76) 
Santa Croce Kilisesi’nde bulunan, bölgedeki Türk varlığına gönderme yapan başka bir uygulama, kilisenin iç mekanında, kuzey bölümünde yer alan şapeldeki San Francesco di Paola Altarı'dır (F.12). Mimar ve heykeltıraş Francesco Antonio Zimbalo'nun (1567-1631) 1614-1615 yılları arasında tamamladığı ve Sternatia ${ }^{18}$ Baronu Giovanni Cicala için gerçekleştirilmiş olan eser, ${ }^{19}$ üç bölümden oluşmaktadır. Orijinal tasarımında, içinde Aziz Francesco di Paola'nın (1416-1507) bir heykelinin bulunduğu bir niş barındıran ortadaki kısımda, günümüzde, 19. yüzyıla tarihlenen ve Alessandro Calabrese'ye atfedilen bir resim bulunmaktadır. ${ }^{20}$ İki yandaki kanatlarda ise (F.13), yoğun bezemeye sahip Korint başlıklı sütunlarla birbirlerinden üçlü gruplar halinde ayrılan altışar kabartma panoda, Aziz Francesco di Paola'nın hayatından çeşitli sahneler tasvir edilmektedir. ${ }^{21}$

1416-1507 yılları arasında yaşamış olan Aziz Francesco di Paola, Güney İtalya'da Calabria Bölgesi'nde Paola kasabasında doğmuştur. Bir Katolik tarikatı olan Minim'in kurucusu olan aziz, kehanetlerinin gerçekleşmesiyle de tanınmıştır. Kendisi, Otranto'nun 1480'de Osmanlılar tarafından ele geçirileceğini ve daha sonra Napoli Kralı tarafından geri alınacağını önceden haber vermiştir. ${ }^{22}$ Azizin yaşamından çeşitli kesitlerin betimlendiği, Donmuş kişinin diriltilmesi, Inzivaya çekilme, Messina Boğazı'ndan cüppe üzerinde geçiş, Bir çocuğun diriltilmesi gibi kabartma panoların arasında iki tanesi, Otranto'daki Türk varlığını göstermesi bakımından önemlidir. Her ikisi de altarın sağ kanadında (F.13) bulunan bu panolardan birincisi Otranto'nun özgürleşmesi için isimli kabartmadır (F.14). Burada, arka planda Osmanlı birlikleri, Otranto Kalesi’ni kuşatmış bir şekilde betimlenmişlerdir. Ön planda ise, Aziz Francesco di Paola, bu kuşatmayı müritlerine işaret ederken tasvir edilmiştir. İkinci pano ise, Otranto'daki Türkleri kuşatan birliklere adak mumu dağıtılması adını taşımaktadır (F.15). Bu kabartmada da aziz, müritleriyle birlikte bir kilisenin önünde, arka plandaki Otranto Kalesi’nin önündeki Türk birliklerini kuşatmaya hazırlanan askerlere adak mumu dağıtırken ele alınmıştır. ${ }^{23}$

18 Sternatia, Güney İtalya'da Puglia Bölgesi’nde Lecce kentine yakın bir kasabadır.

19 Paone, a.g.e., 1979, s. 154.

20 Fiorella Congedo, Guide to Lecce, Congedo Editore, Lecce, 1995, s. 86.

21 Paone, a.g.e., 1979, s. 154.

22 Lawrence Hess, "St. Francis of Paula", The Catholic Encyclopedia, Cilt 6, Robert Appleton Company, New York, 1909, http://www.newadvent.org/cathen/06231a.htm, 14 Mart 2019.

23 Michele Paone, Guida di Santa Croce, Congedo Editore, İtalya, 1994, s. 44. 


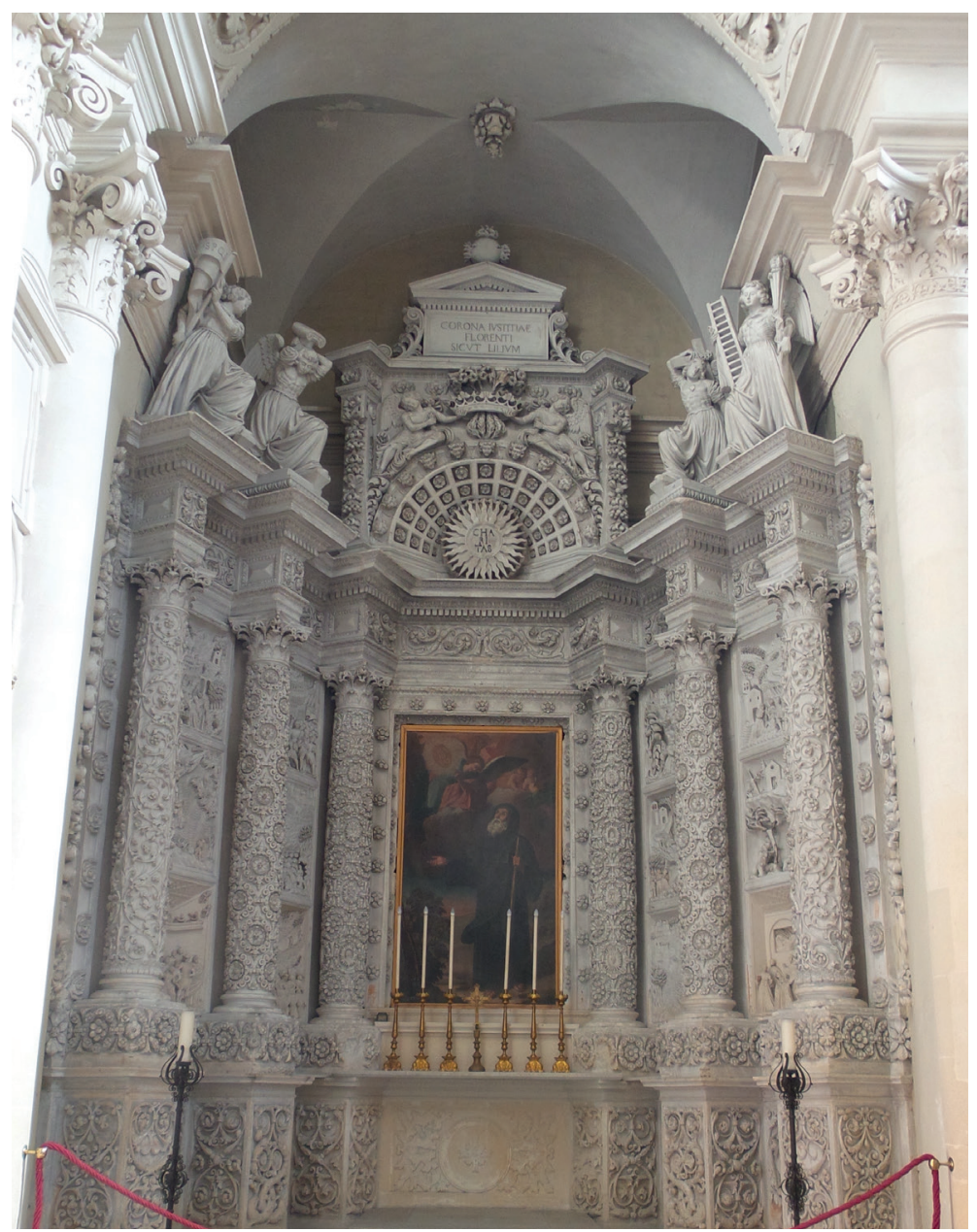

F. 12: Lecce, Santa Croce Kilisesi, San Francesco di Paola Altar1 


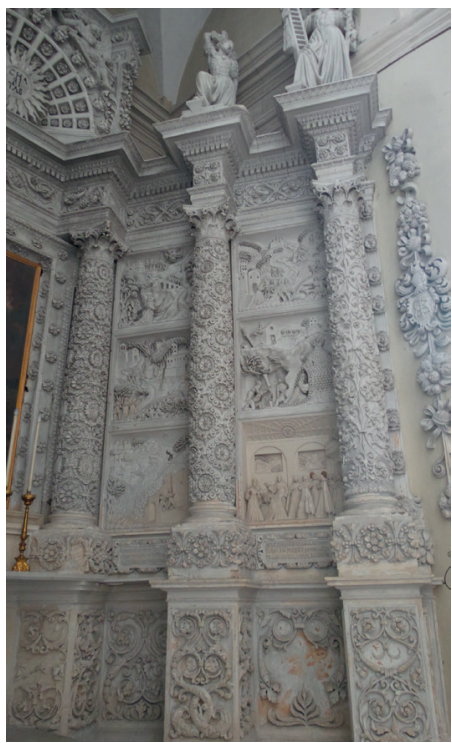

F. 13: Lecce, Santa Croce Kilisesi, San Francesco di Paola Altarı, sağ kanat

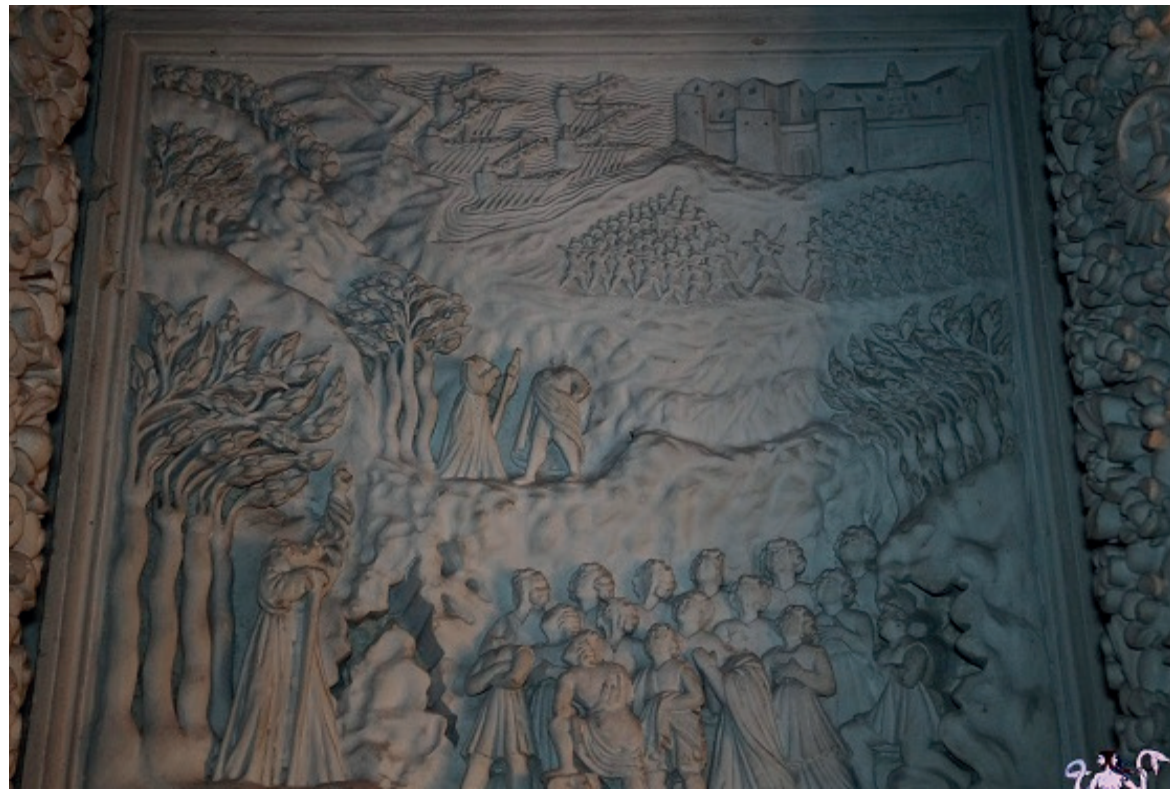

F. 14: Lecce, Santa Croce Kilisesi, San Francesco di Paola Altar1, kabartma pano 


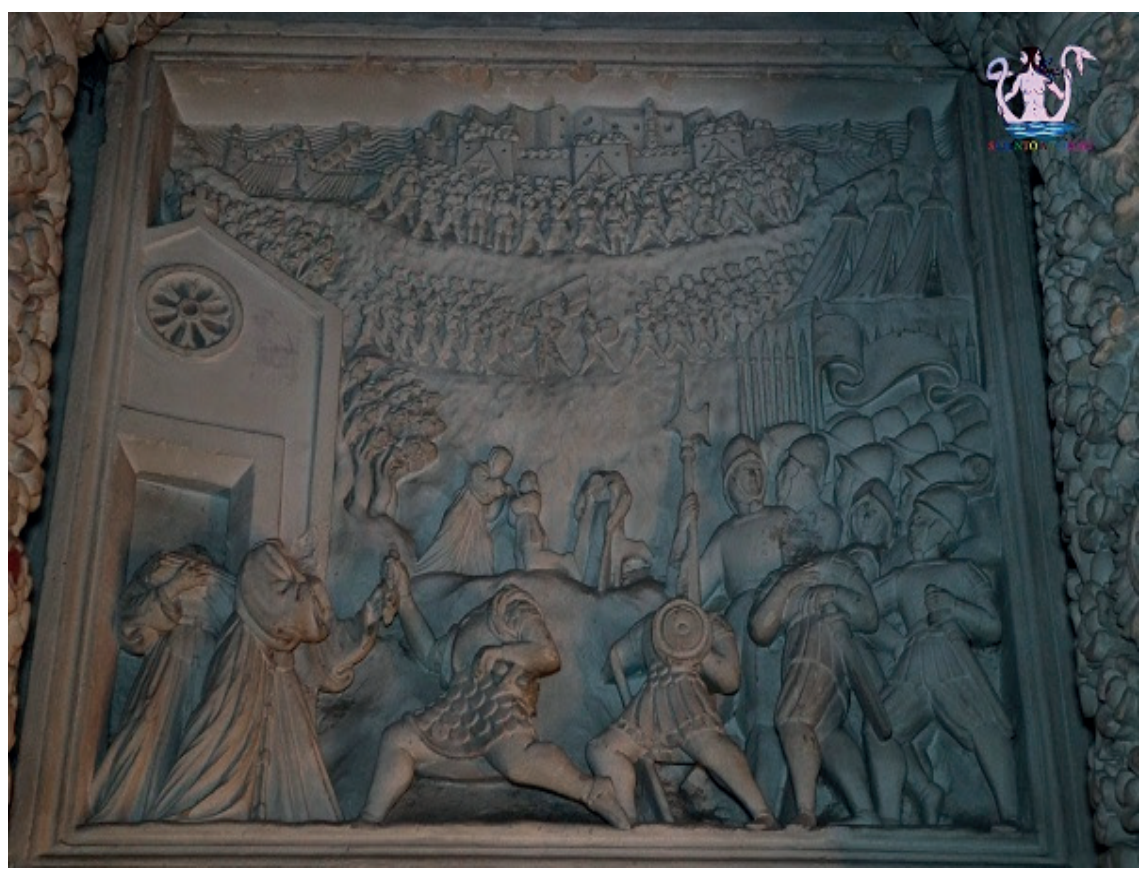

F. 15: Lecce, Santa Croce Kilisesi, San Francesco di Paola Altarı, kabartma pano

\section{Lecce Mimarisi Üzerinde Türk Sanatı Etkileri?}

Yukarıda verilen örnekler, İtalya'nın bu bölgesinde varlık göstermiş olan Türklere ilişkin imgenin sanattaki yansımaları olarak karşımıza çıkmaktadır. Türk-İtalyan etkileşiminin kanıtları sayılabilecek bu örneklerin de ötesinde, bu yazıda işaret edilen önemli bir nokta, söz konusu etkileşimin bir sonucu olarak, Türk sanatının doğrudan Lecce mimarisini etkilemiş olabileceği ihtimalidir. Bu olasılığg düşündüren şey, Lecce'ye yaptığımız araştırma gezilerinde, buradaki Barok üsluplu yapıların bazılarında tespit ettiğimiz ve özellikle mimar ve heykeltıraş Giuseppe Zimbalo'nun (1620-1710) kullandığı süsleme motifleridir. Türk sanatının, halı, cilt, minyatür, maden, ahşap gibi alanlarında 16. ve 17. yüzyıllarda yoğun bir şekilde görülen ve aşağıda etraflıca açıklanan palmet ve salbekli şemse formlarına benzeyen bu motiflerin, yaklaşık olarak aynı dönemde Lecce'deki Barok mimaride ortaya çıkması, iki kültür arasında bir etkileşim gerçekleşmiş olabileceğine işaret etmektedir. Bu temas, gerek savaş yoluyla (Otranto ya da İnebahtı), gerekse de ticari yollarla olmuş olabilir; zira Lecce, Osmanlı'ya ait halı, kumaş, minyatürlü yazma ve birçok küçük el sanatı örneğinin ulaştığı bir nokta olan Venedik ile çok sıkı ticari ilişkilere sahip olmuştur. ${ }^{24}$ Lecce' deki Barok mimaride saptadığımız başka özel bir form ise, Osmanlı mimarisindeki Bursa kemerini anımsatan mimari öğedir.

24 Calvesi, Manieri-Elia, a.g.e., s. 25-27. 
"Bir sapın iki tarafında simetrik olarak sıralanmış uzunca yapraklardan oluşan üsluplaştırılmış bitkisel bezeme öğesi” olarak tanımlanan ${ }^{25}$ ve Türk süsleme sanatında, her dönemde çokça kullanılan bir motif olan ${ }^{26}$ palmete, çini, kumaş, maden gibi birçok değişik malzeme üzerinde rastlanmaktadır. Bu öğenin Türk sanatında çini üzerindeki bir uygulaması aşağıda görülebilir (F.16).

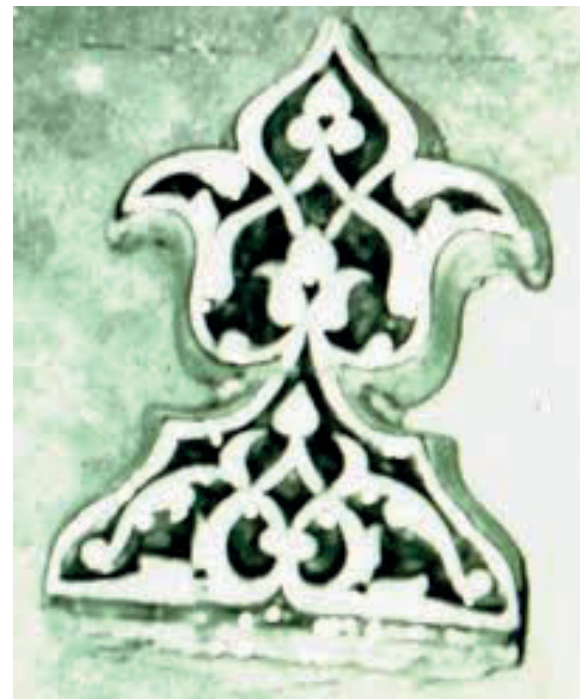

F. 16: Çini palmet örneği, Türk İslam Eserleri Müzesi (Cantay, 2008, s. 40)

Bu motife cephelerinde sıkça rastlanılan, Lecce'de 17. yüzyılda inşa edilmiş olan Barok üsluplu yapılardan önemli bir tanesi, İtalyanca' da Duomo ismiyle de anılan katedral binasıdır (F.17). Piskopos Luigi Pappacoda'nın (1595-1670) himayesinde, 1659-70 y1lları arasında tamamlanan Lecce Katedrali, Bakire Meryem'in Göğe Yükselişi’ne adanmıştır. ${ }^{27}$ Yapının inşasında mimar Giuseppe Zimbalo ${ }^{28}$ görevlendirilmiştir. ${ }^{29}$

25 Metin Sözen, Uğur Tanyeli, Sanat Kavram ve Terimleri Sözlüğü, Remzi Kitabevi, İstanbul, 2011, s. 236.

26 Gönül Cantay, “Türk Süsleme Sanatında Meyve”, Turkish Studies: International Periodical for the Languages, Literature and History of Turkish or Turkic, Cilt 3/5, Güz 2008, s. 33.

27 Paone, a.g.e., 1979, s. 94.

28 Mimar ve aynı zamanda heykeltıraş olan Giuseppe Zimbalo hakkında, kaynaklarda ne yazık ki katkıda bulunduğu yapıların dışında, fazla bir biyografik bilgiye ulaşılamamaktadır. İtalyan araştırmacı Michele Paone (1938-2001), Giuseppe Zimbalo'nun, yine mimar ve heykeltıraş olan ve yukarıda San Francesco di Paola Altarı'nı tasarlayan sanatçı olarak bahsedilen Francesco Antonio Zimbalo'nun torunu olduğunu, Lecce'de bulunan ve ilk çalıştı̆̆ yapılardan biri olan Santa Teresa Kilisesi'nde tasarlamış olduğu Azize Teresa’ya adanmış olan altarda Gioseppe Ximalo csopiva ("Heykeltıraşlığını Giuseppe Zimbalo yaptı.”) şeklinde imzasını bıraktığını, Piskopos Luigi Pappacoda'nın himayesinde faaliyet gösterdiğini ve süslemeci anlayışın hakim olduğu özel bir mimarlık dili yarattığını belirtmektedir (Bkz. Michele Paone, Architetti in Lecce dal Rinascimento al Rococo, Edizioni Grifo, Lecce, 2010, s. 54). Sanatçının ismi kaynaklarda, lakabı olan lo Zingarello ("küçük çingene") şeklinde de geçmektedir (Bkz. Manieri Elia, a.g.e., 1996, s. 102).

29 Teodoro Pellegrino, Piazza Duomo a Lecce, Editoriale Adda, Bari, 1972, s. 37-38. 


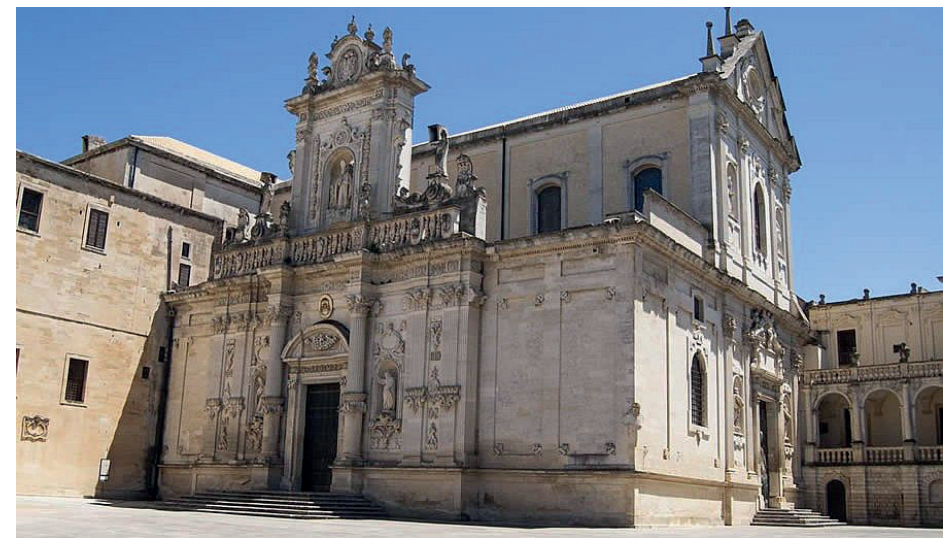

F. 17: Lecce Katedrali

Oldukça sade bir tasarıma sahip olan kilisenin ön cephesinde (F.18), iki yanında Aziz Pietro ve Aziz Paolo'nun heykellerinin bulunduğu giriş portalının solunda, köşeleri İtalyanca mimarlık literatüründe punta lanceolata ("mızrak ucu”) olarak adlandırılan ve Giuseppe Zimbalo'nun sıkça kullandığı motiflerle süslenmiş olan geometrik alanlar yer almaktadır (F.19-20). ${ }^{30}$

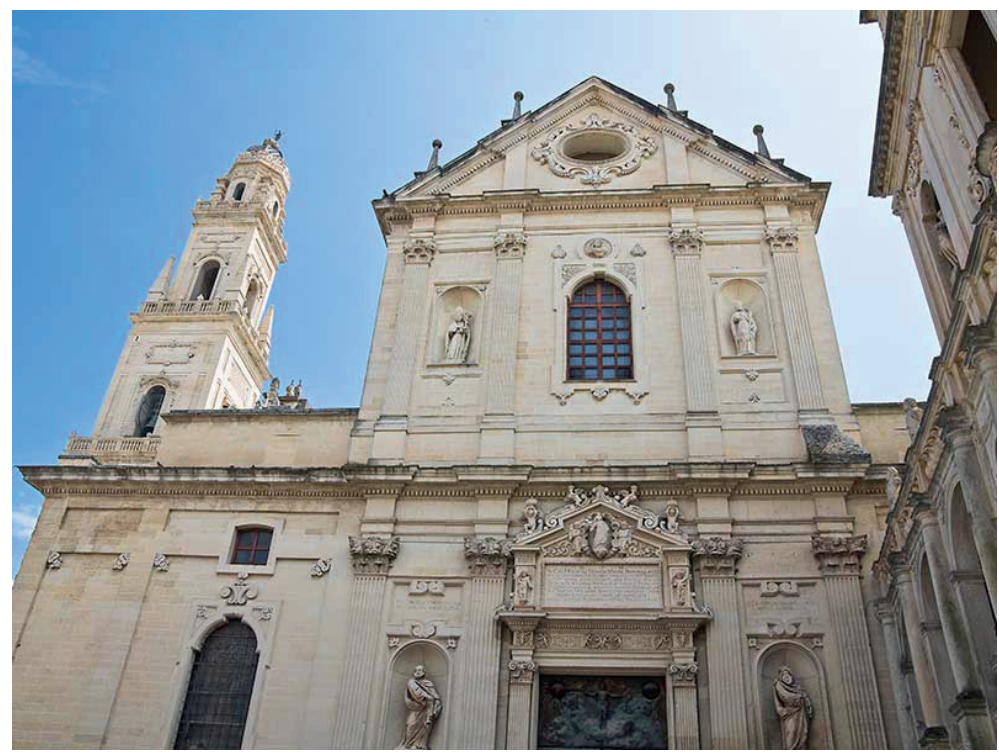

F. 18: Lecce Katedrali, ön cephe

30 Paone, a.g.e., 1979, s. 94. 


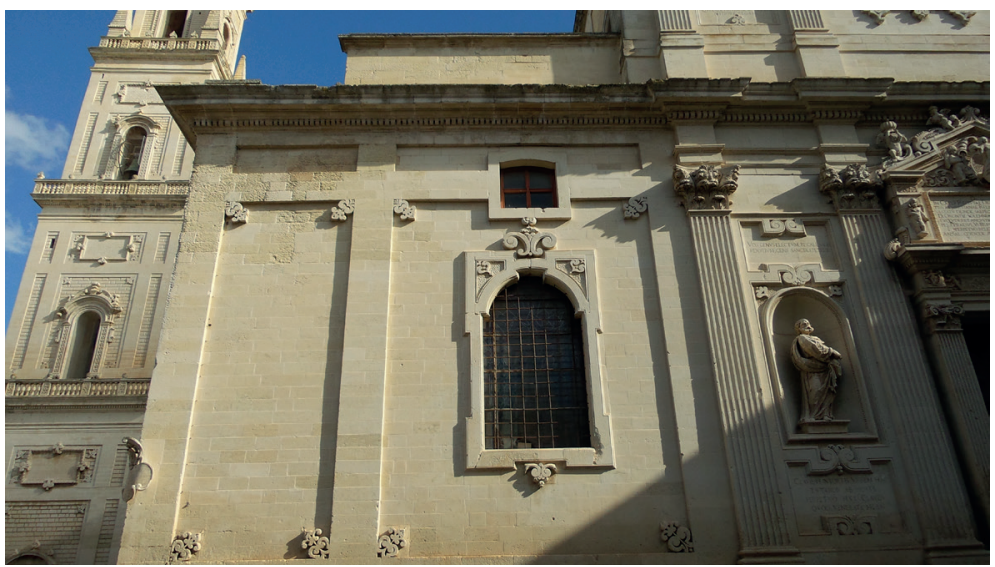

F. 19: Lecce Katedrali, ön cephe

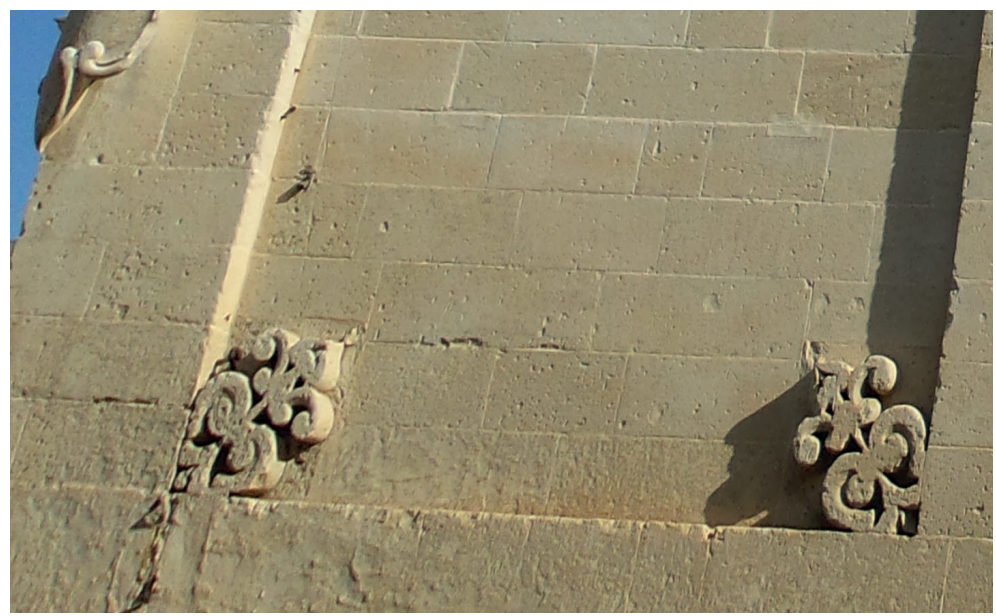

F. 20: Lecce Katedrali, ön cephe, ayrınt1

Bu mızrak ucu motifine yakından bakıldığında (F.21), Türk sanatındaki palmet öğesiyle olan benzerliği dikkati çekmektedir. Örneğin, F.16 figüründeki çini palmet tasarımı, katedraldeki motifin üst kısmıyla paralellik göstermektedir. Palmet motifi, Osmanlı maden sanatının önemli bir uygulama alanı olan ve Osmanlı askeri yaşamında kullanılan ajur desenli sancak alemlerinde de kullanılmıştır. ${ }^{31}$ Bu alemlerin bir örneği aşağıda verilmiştir (F.22). Görüldüğü gibi, kilisedeki motif ile yine bir benzerlik ilişkisi bulunmaktadır. Aynı bezeme öğesi, Türk kumaşlarında da yer almaktadır. F.23 figüründe görülen ve günümüzde Benaki Müzesi’nde bulunan 16. yüzyıla ait kumaş parçası için şu bilgiler aktarılmaktadır: "Bu çatma yastığın

31 Hasan Tuluk, Türk Süsleme Sanatları İçinde Metal Sanatı, Milli Eğitim Bakanlığı Yayınları, Ankara, 2008, s. 118-119. 
zemini lâme olup içi ve bordürleri alem şeklinde süslenmiş, bunların ortalarına da ay şekilleri yapılmıştır." ${ }^{2}$ Bu kumaştaki palmet motifleri de, Giuseppe Zimbalo’nun kullandığı mızrak ucu motifi ile ilişkili düşünülebilir.

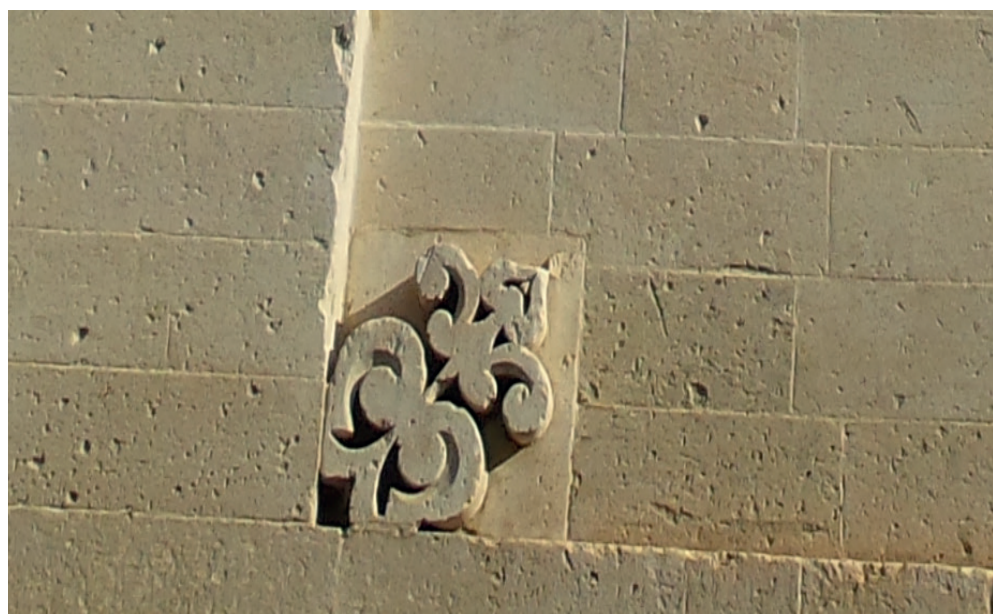

F. 21: Lecce Katedrali, ön cephe, ayrınt1

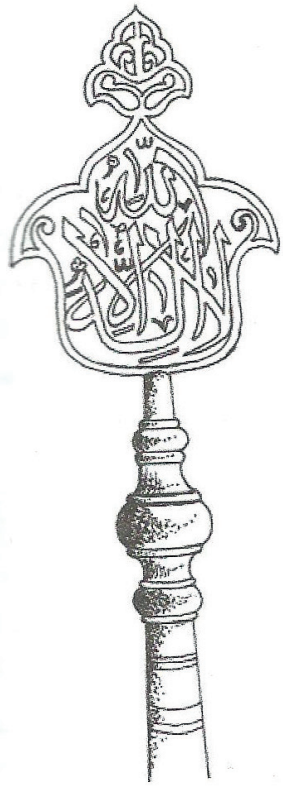

F. 22: Sancak alemi, Askeri Müze (Tuluk, 2008, s. 118)

32 Tahsin Öz, Türk Kumaş ve Kadifeleri, Cilt 2, Milli Eğitim Basımevi, İstanbul, 1951, s. 118. 
Eğer burada düşünüldüğü gibi, Lecce'de İtalyanlar ve Türkler arasında bir kültürel etkileşim olduysa ve bunun sonucunda, Lecce'deki mimariye Türk sanatına özgü bazı öğeler girdiyse, bu formların Lecce mimari dağarcığına birebir alınmadığı; bazı yorumlarla değişikliğe uğradığı görülmektedir. Zimbalo’nun, söz konusu süsleme motiflerini değişik bir stilizasyonla yorumlamış olması muhtemeldir. Burada örnekleri verilmiş olan, Türklere ait bir kumaş örneği ya da bir sancak alemi gibi nesnelerin, çeşitli yollarla (Otranto Kuşatması gibi) Lecce’ye ulaşmış olması kuvvetli bir ihtimaldir.

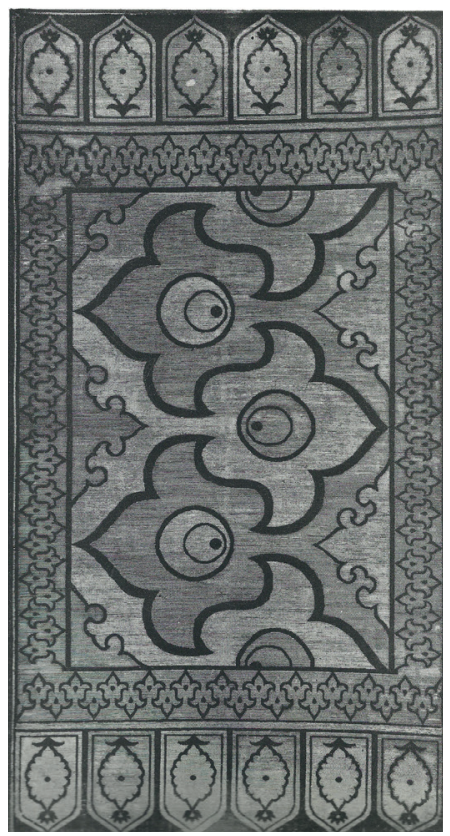

F. 23: Çatma yastık, 16. yüzyıl, Benaki Müzesi (Öz, 1951, s. 119)

Lecce Katedrali'nin yan cephesinde de tekrar eden palmet benzeri motif, yapının iç mekanında da birçok noktada karşımıza çıkmaktadır. F.24 figüründe bir örneği verilen, bir şapelin yan duvarına taşa oyulmuş olarak oluşturulmuş form, yukarıda ortaya atılmış olan, bu bölgenin, buraya ulaşan ve Türklere ait olan çeşitli nesneler yoluyla, Türk sanatından etkilenmiş olabileceği olasılığını güçlendirmektedir. Zira, F.16, F.22 ve F.23'e tekrar bakıldığında, Türk sanatındaki palmet motifi ve kilisenin içinde kullanılmış olan bezeme öğesi (F.24) arasındaki benzerliğin ne kadar çarpıcı olduğu hemen fark edilecektir. 


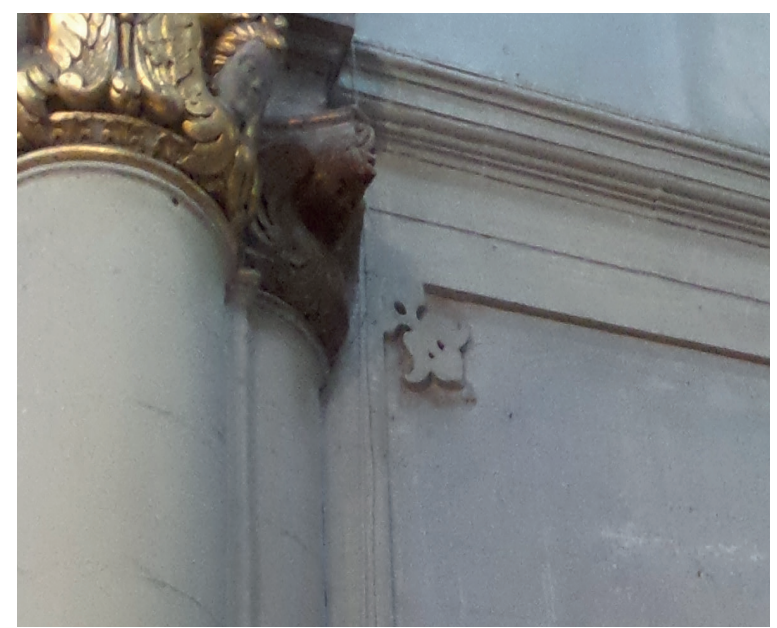

F. 24: Lecce Katedrali, iç mekan, ayrıntı

Benzer bir motif, katedralin kuzey duvarına bitişik bulunan ve İtalyanca Il Campanile olarak adlandırılan Çan Kulesi'nde de görülmektedir. Yine mimar Giuseppe Zimbalo tarafindan tasarlanan ve yapımı 1661-1682 yılları arasında tamamlanan kule (F.25), ${ }^{33}$ kesme taşlarla oluşturulmuş alanların köşelerinin palmet benzeri motiflerle süslenmesiyle (F.26), Zimbalo'nun estetik anlayışını yansıtmaktadır.

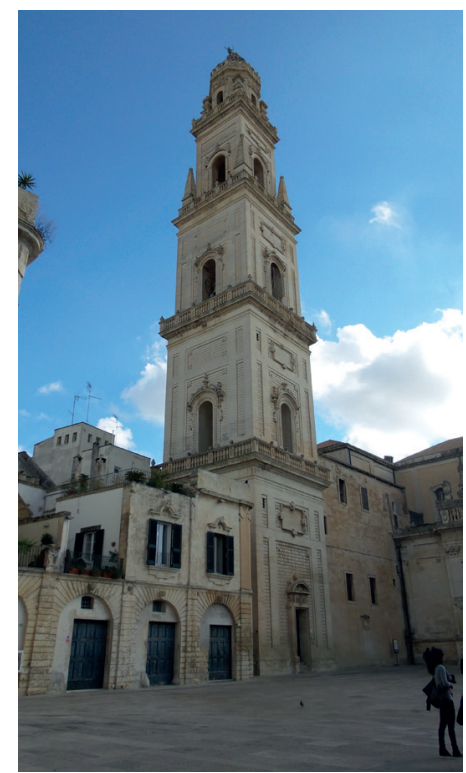

F. 25: Lecce Katedrali, Çan Kulesi

33 Congedo, a.g.e., s. 49. 


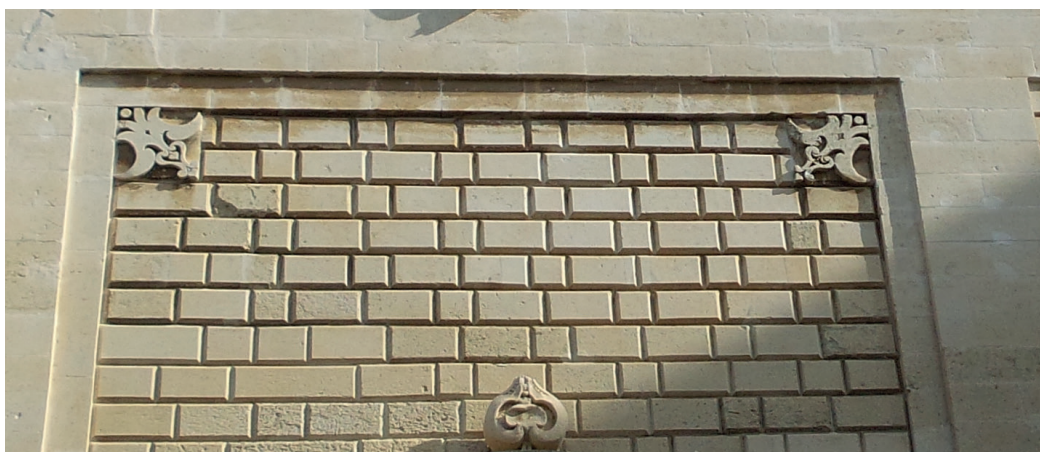

F. 26: Lecce Katedrali, Çan Kulesi, ayrıntı

Bu palmet benzeri motiflere yakından bakıldığında (F.27), Zimbalo’nun bu form üzerinde, katedral cephesinde olduğundan daha farklı bir stilizasyon uyguladığı dikkati çekmektedir. Bu motifin, Türk maden sanatı örneklerinden biri olan gümüş bir kutu kenarı bezemesindeki palmet motifleriyle (F.28) olan benzerliği çarpıcıdır. Kule cephesinde, Türk süsleme sanatı repertuarına ait bir forma çok yakın bir motifin kullanılmış olması, yine, bir kültür etkileşimi ihtimalini kuvvetlendirmektedir.

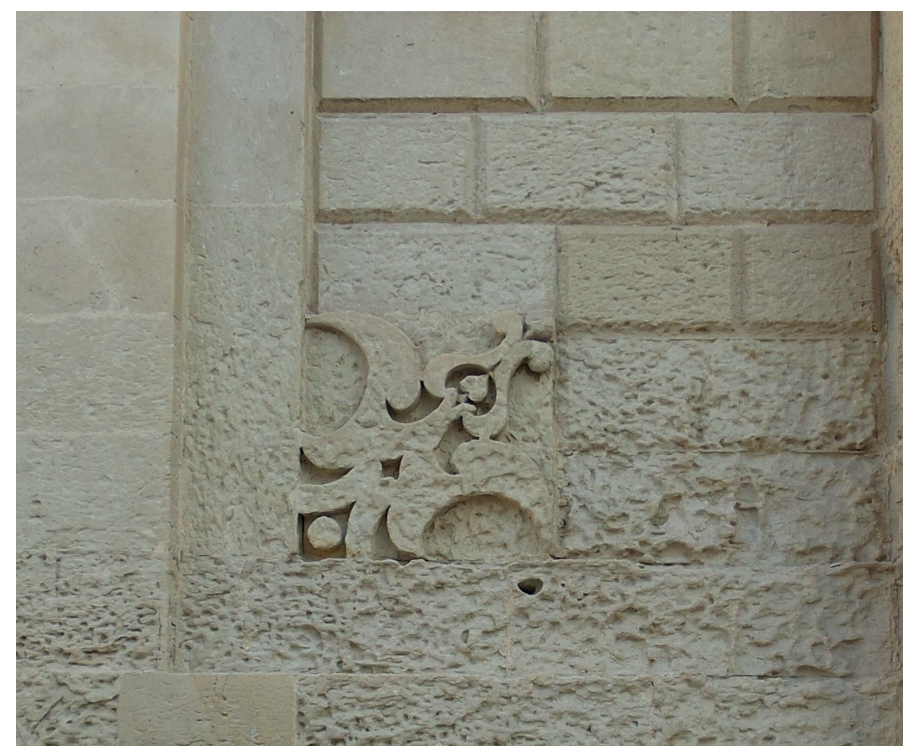

F. 27: Lecce Katedrali, Çan Kulesi, ayrıntı 


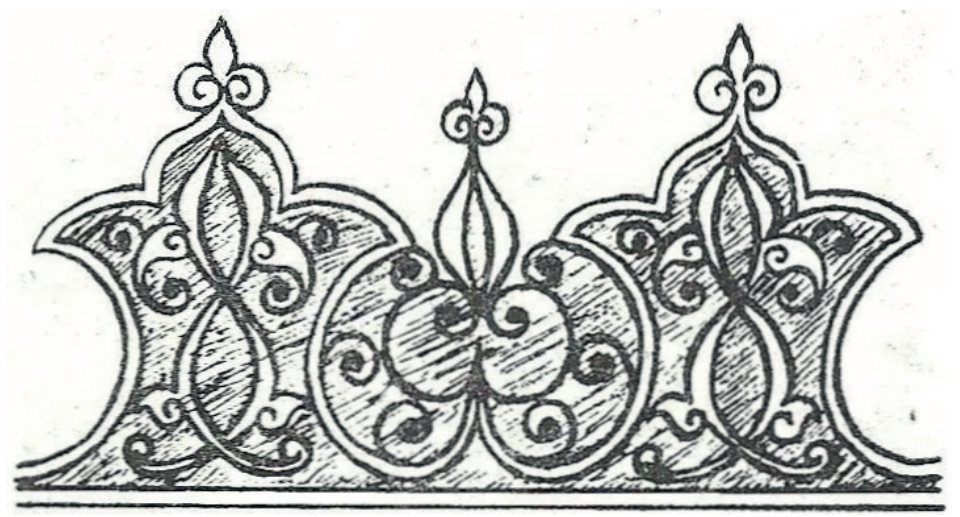

F. 28: Gümüş kutu kenarından bir Türk süsleme sanatı örneği (Züber, 1972, s. 112)

Lecce'deki Barok mimaride tespit ettiğimiz ve Türk süsleme sanatı ile ilişkilendirilebilecek diğer bir motif, iki yana uzantıları olan madalyon formudur. Lecce'de birden çok yapıda görülen bu formun en çarpıcı örnekleri, mimar Giuseppe Zimbalo'nun son tasarımı olan ve Dominiken Tarikatı için 1691 yılında inşa edilen ${ }^{34}$ San Giovanni Battista Kilisesi’nde bulunmaktadır (F.29). Söz konusu motif bu yapının ön cephesinde, (dörtgen formlu ve duvara yapışık sütun şeklindeki mimari öğe olan) plastırların, ${ }^{35}$ yarım plastırların üzerine ve de nişlerin alt ve üst kısımlarına, hem tam, hem de yarım madalyon olarak yerleştirilmiştir (F.30). İslam sanatındaki iki yana uzantılara sahip olan madalyon formu "salbekli şemse" motifine benzeyen bu formun, Lecce'nin mimari süsleme dağarcığına hangi yollarla girmiş olabileceği sorusunun muhtemel cevabı, palmet motifinde olduğu gibi, Türk sanatından bazı eserler incelenerek araştırılabilir. Arapça "güneş" anlamına gelen "şems" kelimesinden türetilmiş olan "şemse", Celal Esad Arseven (1875-1971) tarafından "Güneş şeklindeki tezyinat örgesi” olarak tanımlanmıştır. ${ }^{36} \mathrm{Bu}$ motif Türk sanatında, halı, kumaş, çini, maden, ahşap, kitap cildi gibi çok değişik uygulama alanlarında kullanılmıştır. Bu alanlardan, Türk halı sanatına bakıldığında, söz konusu madalyon formunun, 16. ve 17. yüzyılda üretilmiş olan Klasik dönem Osmanlı halılarının belirleyici unsuru olduğu görülmektedir. Şemse formu bu dönemde, Uşak halıları ve Osmanlı saray halıları olarak gruplandırılan Türk halılarının tümünde görülen ortak motiftir. Klasik dönem Osmanlı halılarının birinci grubu olan “Madalyonlu Uşak Halıları”nın genel şeması şöyledir: "Değişen sıralar üzerinde yer almış iki şekilde madalyon vardır. Orta eksende yuvarlak madalyonlar, yan eksenlerde sivri dilimli madalyonlar sıralanmıştır. [...] Her madalyon alt ve üst uçlarından çıkan kalkan veya salbek şekli ile uzatılmıştır. [...] Yuvarlak madalyonların içinde, mavi, sarı, kırmızı dolgulu dört palmet ve karşılıklı çifte rumilerden meydana gelmiş kapalı bir motif

34 Paone, a.g.e., 1979, s. 127.

35 "Pilastr" olarak da yazılan mimari öğe, "Dörtgen planlı ve bir yanından duvara bitişik yarım sütun" şeklinde tanımlanmaktadır (Bkz. Sözen, Tanyeli, a.g.e., s. 244).

36 Celâl Esad Arseven, Sanat Ansiklopedisi, Cilt IV, Milli Eğitim Basımevi, İstanbul, 1975, s. 1880. 
yer alır. Uçları birer palmetle taçlanmıştır." ${ }^{37} \mathrm{Bu}$ genel şema (F.31), San Giovanni Battista Kilisesi’nin cephesindeki madalyon motifli tasarımla (F.32) karşılaştırıldığında, aralarındaki şaşırtıcı benzerlik fark edilebilir.

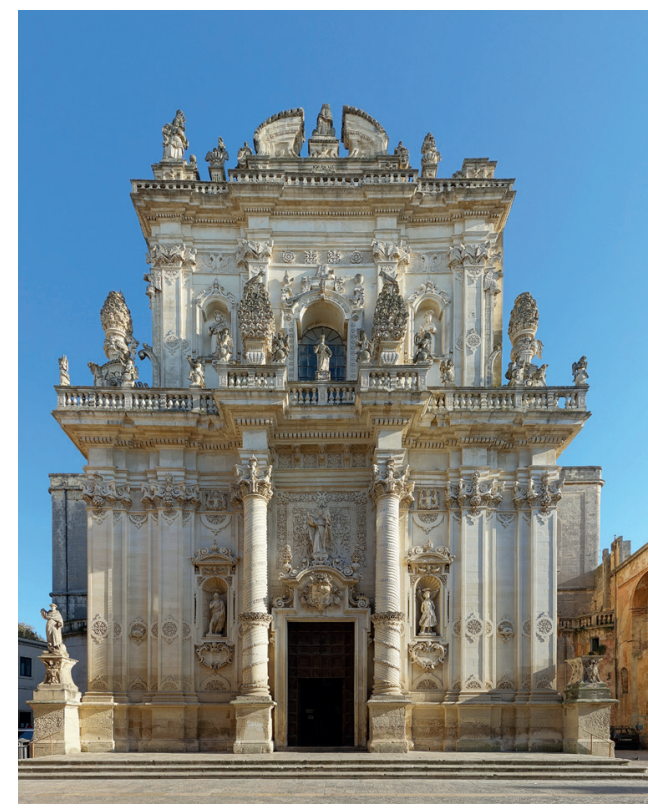

F. 29: Lecce, San Giovanni Battista Kilisesi

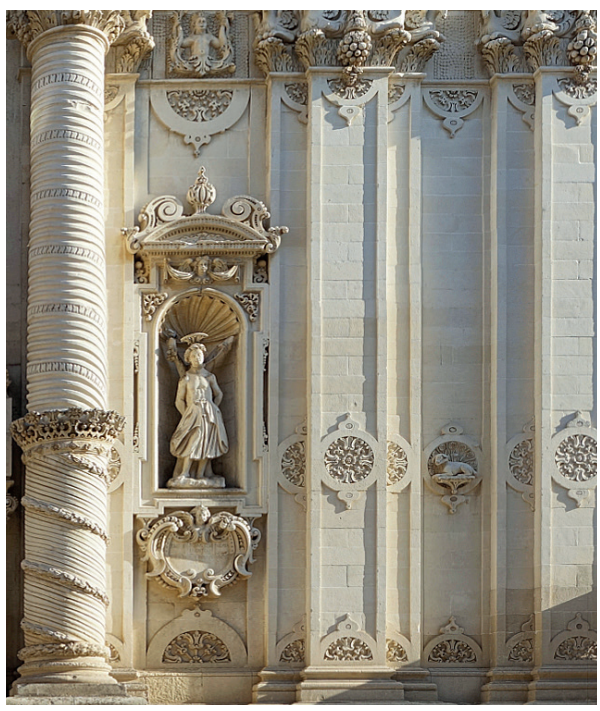

F. 30: Lecce, San Giovanni Battista Kilisesi

37 Şerare Yetkin, Türk Halı Sanatı, Türkiye İş Bankası Kültür Yayınları, Ankara, 1991, s. 87-88. 


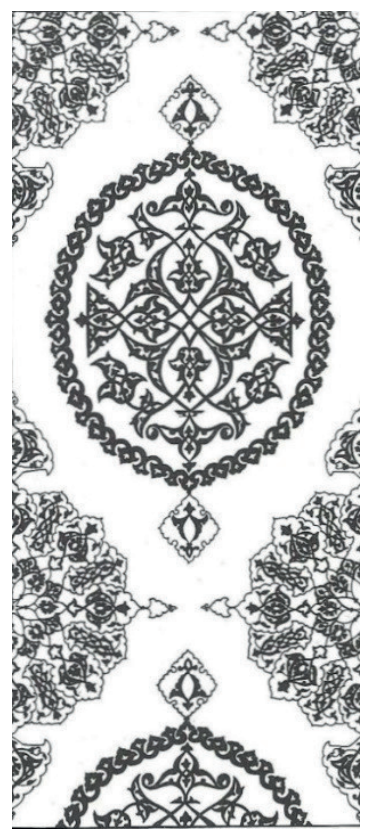

F. 31: Bir Madalyonlu Uşak Halısının genel şeması Battista Kilisesi (Yetkin, 1991, s. 89)

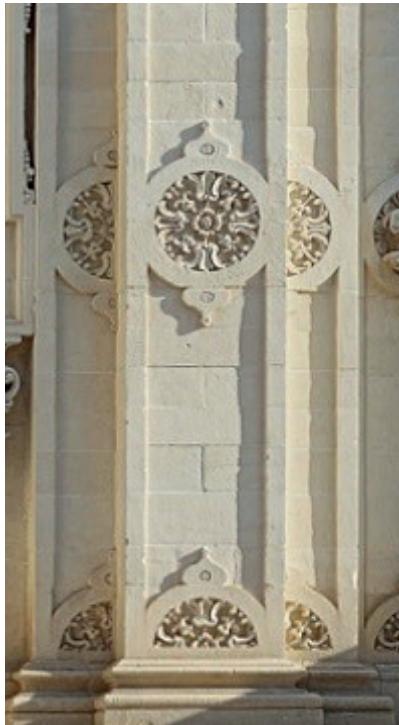

F. 32: Lecce, San Giovanni

Her iki tasarımda da, uzantıları bulunan tam ve yarım madalyon motiflerinin aynı eksen üzerinde kullanımı söz konusudur. Kilisenin cephesindeki, Batı sanatındaki formlardan ziyade, Türk süsleme repertuarındaki motiflerle ilişkilendirilebilecek olan bu uygulamanın muhtemel bir kaynağı, yukarıdaki benzerlikten anlaşılacağı gibi, Türk halı sanatıdır. Bunun güçlü bir ihtimal olmasının sebeplerinden biri, madalyonlu Uşak halılarının, 16. yüzyılda Avrupa’ya ihraç edildiklerinin bilinmesidir. Bu halılar ayrıca, 16. ve 17. yüzyıllarda Batılı ressamların tablolarında da tasvir edilmişlerdir. ${ }^{38}$ Dolayısıyla, bu motif, hem dolaşımda olan objenin (halı gibi) kendisine ulaşılmasıyla, hem de bu formun tasvirinin görülmesiyle, Lecce'deki mimari süsleme diline katılmış olabilir.

Lecce'nin Venedik'le yoğun ticari ilişkilere sahip olduğu, Venedik'ten Lecce'ye, Doğu'dan gelen ipek, halı ve bunun gibi pek çok değerli nesnenin giriş yaptığı ve mimar Giuseppe Zimbalo'nun bu nesnelerdeki imgelerden etkilenmiş olabileceği belirtilmektedir. ${ }^{39}$ Osmanl Devleti'nin Venedik'le 16. ve 17. yüzyıllarda sahip olduğu ticari bağın 1573-1645 yılları arasında daha da güçlenmiş olduğu, Türk tüccarların Venedik’te sabit bir ikametgâh edinme hakkına kavuştukları ve burada kumaş ve halı ticareti yaptıkları göz önünde bulundurulduğunda, ${ }^{40}$ Türk

38 Yetkin, a.g.e., s. 90.

39 Calvesi, Manieri-Elia, a.g.e., s. 27.

40 Osmanlı Devleti ve Venedik Cumhuriyeti arasındaki ticari ilişki şu şekilde tarif edilmiştir: “Türk tüccarlar çok eskiden beri vardır Venedik’te, öyle ki sonunda Venedik'te sabit ikametgâh edinme hakkı da elde ederler. 1573 
halılarının Lecce’ye ulaşmış olma olasılığının ne kadar kuvvetli olduğu anlaşılabilir. Lecce kentinin en merkezi alanı olan Sant'Oronzo meydanında, söz konusu dönemde, Venedik'li tüccarların dükkanlarının bulunduğu ve onlar için bu meydanda, San Marco Şapeli'nin inşa edildiği aktarılmaktadır. ${ }^{41}$ Türk halılarının veya başka nesnelerin bu dükkanlar yoluyla Lecce'de dolaşıma girmiş olmaları kuvvetle muhtemeldir. Lecce San Giovanni Battista Kilisesi’nin cephesindeki madalyon motifi (F.33) ile Uşak halılarındaki salbekli şemse formunun benzerliği, F.34, F.35 ve F.36'daki halı örneklerinde de görülebilir.

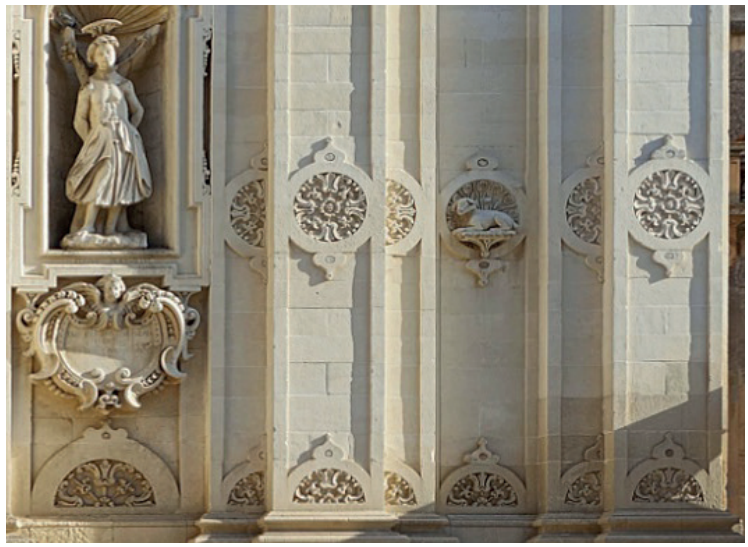

F. 33: Lecce, San Giovanni Battista Kilisesi

ile 1645 yılları arasındaki barış dönemi, alışverişin düzenli hale getirilmesi açısından çok yararlı olmuştur. Osmanlı tüccarları öncelikle bir alış-veriş semti olmakla birlikte meyhane ve genelevlerin de bulunduğu San Matteo di Rialto'da 1575 yılında kurulan Fontico de' Turchi'de yerleştiler. Onlarla iş yapan simsarların bu misafirhaneye gitmeleri gerekiyordu. [...] 1621 yılında Türkler, Büyük Kanal kıyısındaki ünlü Fondaco dei Turchi'ye geçtiler; burası onların ihtiyaçlarına cevap verecek biçime yeniden düzenlenmiş bir saraydı. Hepsinin topluca kalabilecekleri bir konutun yanı sıra, bütün mallarını depolayabilecekleri dükkanlar, ibadethane ve hamam da tahsis edilmiş oluyordu. [...] 300 tüccara kadar barındırabilirdi ama Türkler muhtemelen hiç bu kadar kalabalık olmamışlardı; en faal oldukları dönemde bile 50 ila 100 kişi kadardılar. İki grup olarak bir araya getirilmişlerdi, Fondaco'nun mekanı içinde birbirlerinden ayrılmışlardı; bir tarafta, şüphe yok ki Türkçe konuşan İstanbul ve Anadolu tüccarları, öteki tarafta ise Balkanlardan gelenler, Arnavutça konuşan Arnavutlar ile Slavca konuşan Boşnaklar bulunurdu. İlk gruptakiler ya deve ya da Ankara keçisi tüyünden yapılma kumaş ve halı ticareti yaparlard1, zambelloti denirdi bunlara; ötekiler ise çeşit çeşit cila, yün ve meşin satarlardı.” Bkz. Lucette Valensi, Avrupa'da Müslümanlar (16.-18. Yüzyıllar), Çev. Alp Tümertekin, Türkiye İş Bankası Kültür Yayınları, İstanbul, 2015, s. 161-162.

41 Calvesi, Manieri-Elia, a.g.e., s. 26. 


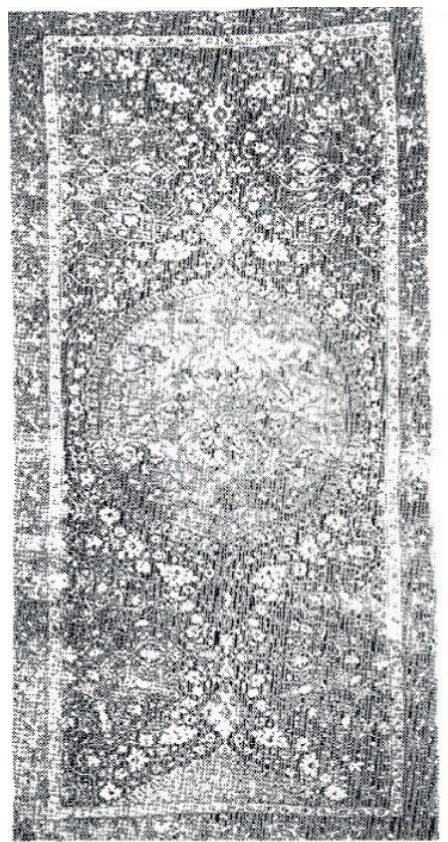

F. 34: Madalyonlu Uşak Halısı, 16. yüzy1l, Hamburg, Museum für Kunst und Gewerbe (Yetkin, 1991, s. 91)

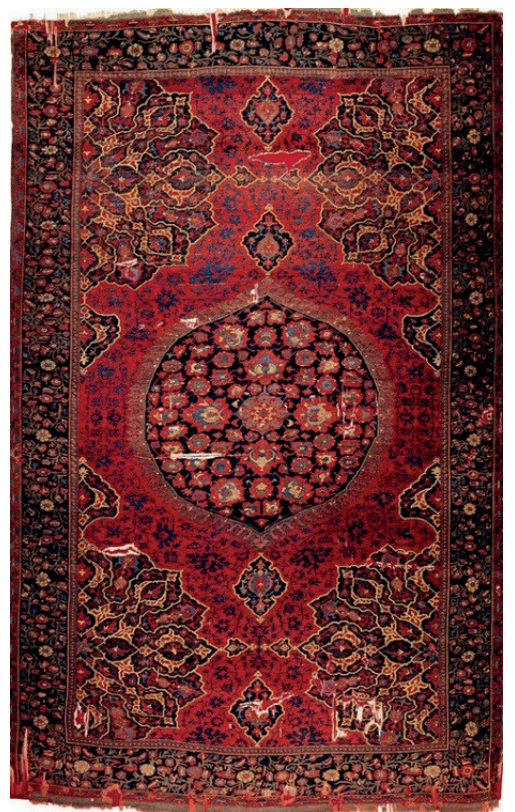

F. 35: Madalyonlu Uşak Halısı, 16. yüzyıl sonu, Özel koleksiyon, New York (Dinçeli, 2019, s. 556) 


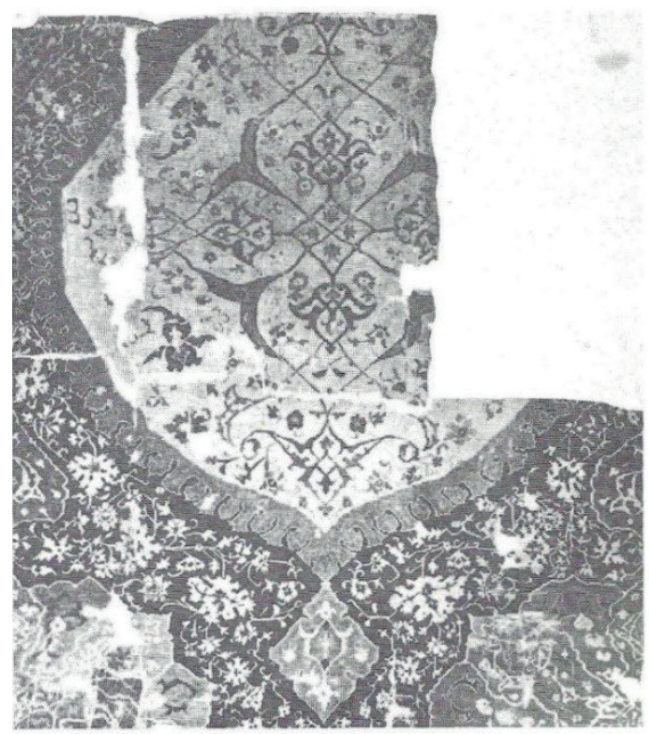

F. 36: Madalyonlu Uşak Halısı, 16. yüzyıl sonu, Berlin, Staatliche Museen

(Yetkin, 1991, s. 91)

Bu halılarda yer alan madalyon motiflerinin içlerinin çeşitli bitkisel bezemeler ve palmetlerle dolgulandığı görülmektedir. Özellikle F.36' daki Uşak halısına bakıldığında, madalyon formunun merkezinde dört yöne doğru ele alınmış dört adet palmet motifi ve bunların, mimar Giuseppe Zimbalo'nun yapılarında kullandığı palmet motifleriyle olan benzerliği dikkati çekmektedir. $\mathrm{Bu}$ form, hem daha önce sunmuş olduğumuz motiflerle (örneğin F.27), hem de San Giovanni Battista Kilisesi'nin ön cephesinde, giriş kapısının üzerinde kullanılmış olan bezeme öğeleriyle (F.37-38) paralellik göstermektedir. Şemse motifinin, genellikle palmet formu ile birlikte kullanılması, bu iki motifin niçin Zimbalo'nun yapılarında aynı anda ortaya çıkmış olduğuna ışık tutabilir. Ayrıca, bu süsleme öğelerinin Lecce'de, Osmanlı sanatı ile aynı dönemlerde görülmesi, bir tesadüften fazlasına işaret etmektedir.

16. ve 17. yüzyılda üretilmiş Klasik Dönem Osmanlı halılarının içindeki bir diğer grup olan "Osmanlı Saray Halıları" da tasarımlarıyla, Lecce'deki Barok üsluplu yapılarda görülen motiflerin kaynakları arasında yer alabilir. Osmanlı saray halıları, 1514 yılında Tebriz'in ve 1517'de Kahire'nin Osmanlılar tarafından ele geçirilmesi sonucunda, Türk halı sanatında yeni bir desen ve teknik anlayışının ortaya çıkmasıyla beraber oluşan bir halı grubudur. $\mathrm{Bu}$ halılarda, İran halılarında ana motif olan madalyon formunun ikincil bir motif haline geldiği, zeminin süslenmesine önem verildiği ve Türk çiçeği olarak adlandırılan lale, sümbül, karanfil ve gül formlarının kullanıldığı belirtilmektedir. ${ }^{42}$

42 Yetkin, a.g.e., s. 116-117. 


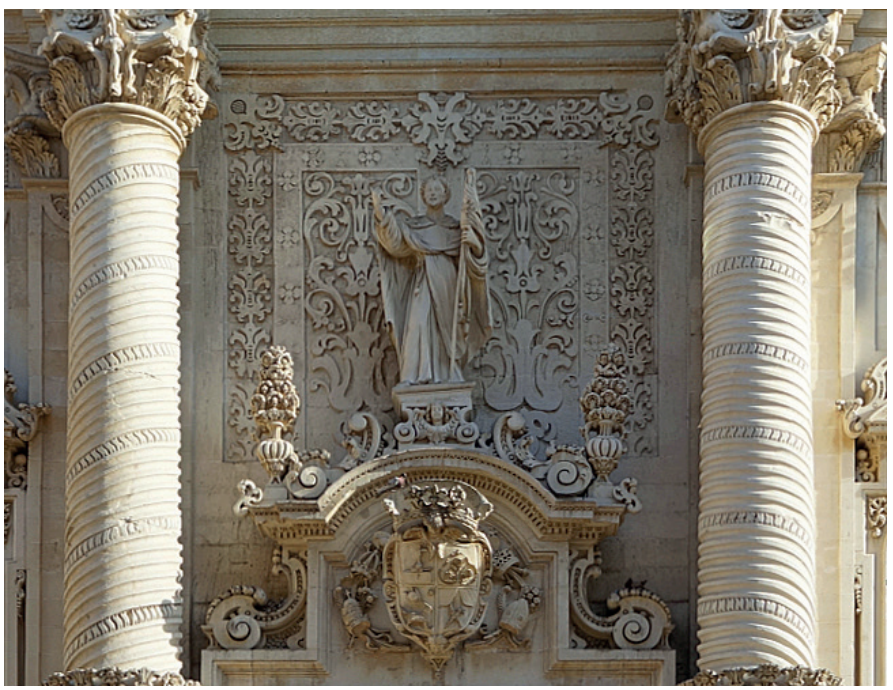

F. 37: Lecce, San Giovanni Battista Kilisesi

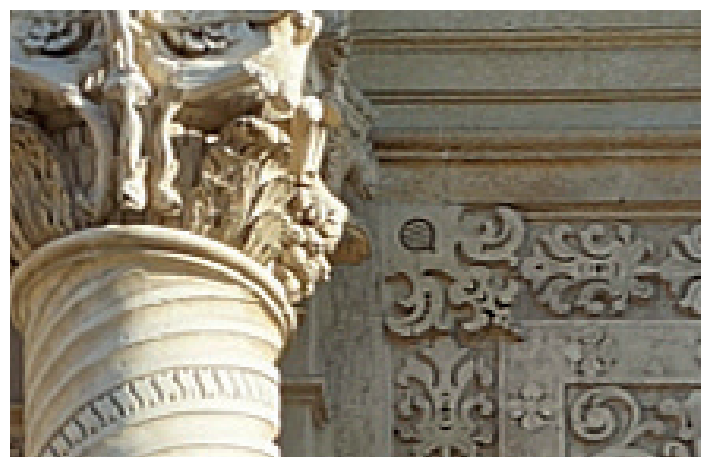

F. 38: Lecce, San Giovanni Battista Kilisesi, ayrınt1

Bu halı grubunun, günümüzde New York Metropolitan Müzesi’nde bulunan bir örneğine bakıldığında (F.39), tam ortada, içinde palmet motifi yer alan bir madalyon ve köşelerde ise sivri dilimli çeyrek madalyonlar görülmektedir. Halının etrafı ise, içinde bitkisel bezemelerin bulunduğu bordürlerle çevrelenmiştir. Bu halı tasarımının, genel görünüş bakımından, dönemin cilt kapaklarının süslemesi ile paralellik gösterdiği; bunun yanı sıra, Osmanlı minyatürlerinde tasvir edilmiş olan halılarla, aynı dönemin orijinal Osmanlı saray halıları arasında yakın benzerlik bulunduğu belirtilmektedir. ${ }^{43}$ San Giovanni Battista Kilisesi’nin cephesindeki şemse formu, örneği F.39'da verilmiş olan halının merkezindeki madalyon motifi ile ilişsilendirilebilir. Madalyonlu Uşak halılarında olduğu gibi, şemse motifi burada yine palmetle beraber ele alınmıştır. Lecce'deki yapılarda bu iki formun bir arada yer almaya başlaması, yine Türk

43 Yetkin, a.g.e., s. 136. 
süsleme sanatı dağarcığg ile etkileşimi düşündürmektedir. Hem madalyon motiflerine, hem de palmet motiflerine (örneğin F.39'daki Osmanlı saray halısının madalyonunun içindeki büyük palmete ve F.38'de San Giovanni Battista Kilisesi'nin ya da F.27'de Lecce Katedrali Çan Kulesinin cephelerindeki palmetlere) bakıldığında, aradaki şaşırtıcı benzerlik görülebilmektedir. Lecce Barok mimarisindeki bu formların kaynağının, bu dönemde üretilmiş bir Türk halısı ya da bu halı tipinin, dönemin minyatürlerinde tüm ayrıntılarıyla yer almış bir tasviri, ya da aşağıda değinileceği gibi, buna benzer tasarımlara sahip, aynı devrin cilt kapakları olması muhtemel gözükmektedir. F.39' daki halının hatırlattığı başka bir Zimbalo uygulaması, yukarıda görülen Santa Croce Kilisesi'nin (F.3) ikinci katında gül pencerenin iki yanındaki nişlerin içinde bulunduğu, sütunlarla sınırlandırılmış dikdörtgen alanların üst köşelerinde yer alan dilimli formlardır (F.40). Batı mimarisindeki süslemelere benzemeyen bu formlar dikkatlice incelendiğinde (F.41), onların Osmanlın saray halısının köşelerindeki dilimli motiflere (F.42) ne kadar benzediği fark edilebilir. Aradaki başka bir benzerlik ise, söz konusu nişin üzerindeki dilimli formları üç yönden çevreleyen ve taşa oyulmuş bitkisel bezemelerle süslenmiş ince bordürlerdir. Bu bordürler, görüldüğü gibi, halıdakilerle paralellik taşımaktadırlar.

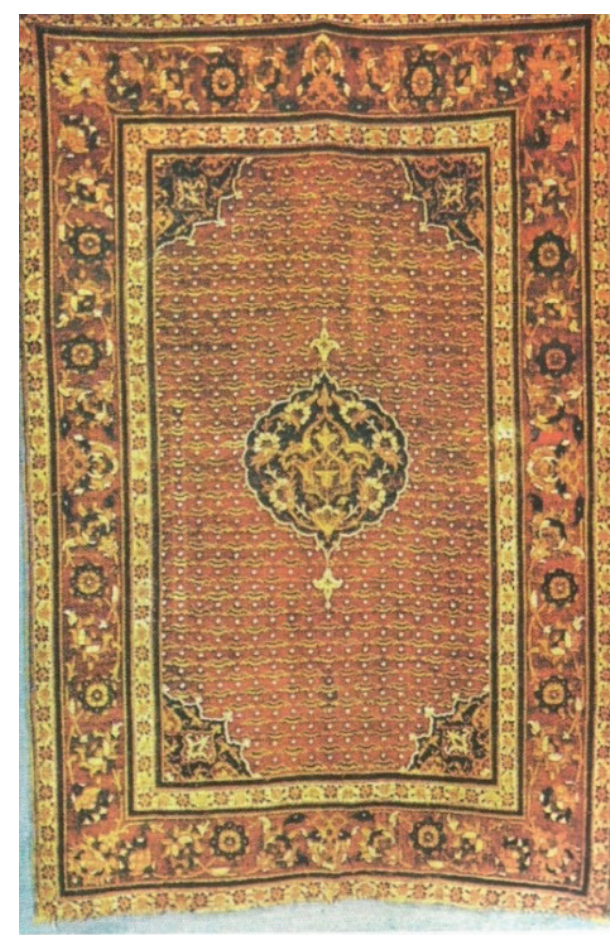

F. 39: Osmanlı saray halısı, 17. yüzy1l, New York Metropolitan Museum of Art (Yetkin, 1991, Levha 75) 


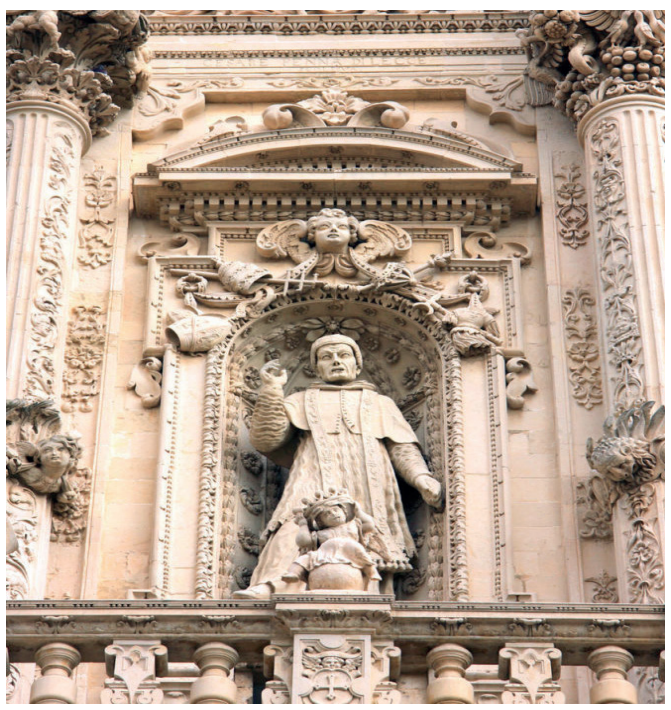

F. 40: Lecce, Santa Croce Kilisesi

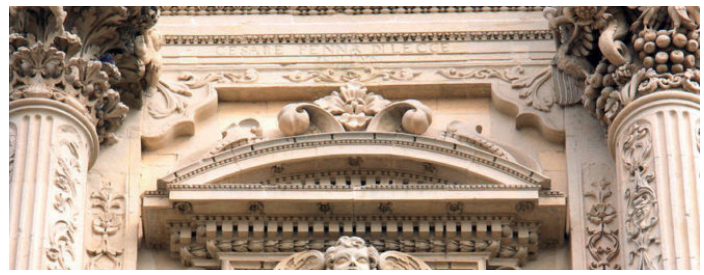

F. 41: Lecce, Santa Croce Kilisesi (ayrıntı)

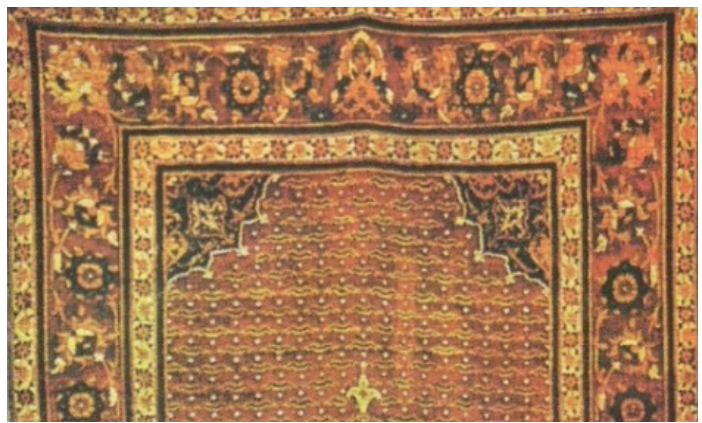

F. 42: Osmanlı saray halıs1, 17. yüzy1l, New York Metropolitan Museum of Art (Yetkin, 1991, Levha 75, ayrınt1)

Osmanlı sanatının, Lecce'deki Barok mimariyi etkilemiş olma olasılığının, tarih boyunca Türkler ve İtalyanlar arasındaki siyasi ve ticari bağlar göz önünde bulundurulduğunda, güçlü bir ihtimal olduğu sonucuna varılabilir. Zira, Türkler ve İtalyanlar arasında temel olarak ticarete 
dayanan siyasi ilişkiler, Ortaçağ’a kadar geriye gitmektedir. Türk-İtalyan siyasi bağlarının kuruluşu, 1207 yılında Anadolu Selçuklu Sultanı I. Gıyaseddin Keyhüsrev’in (ö. 1211) Venediklilerle imzaladığı bir ticaret antlaşmasına tarihlenmektedir. Venediklilere, Selçuklu topraklarında serbest ticaret, serbest dolaşım haklarını ve düşük gümrük vergisi kolaylığını tanıyan bu antlaşma, daha sonra Sultan I. İzzeddin Keykâvus ve I. Alaeddin Keykubat dönemlerinde de yenilenmiştir. Söz konusu ilişki, Anadolu Selçuklularının 14. yüzyıl başında çöküşünden sonra da devam etmiş; Venedikliler Anadolu'daki ticaret imkanlarını kaybetmemek için, Batı Anadolu beyliklerinden Aydınoğulları, Menteşeoğulları ve Osmanoğulları ile siyasi ve diplomatik ilişkiler kurmuşlardır. Örneğin, Aydınoğullarının başkenti olan Selçuk’ta bir konsolosluk açmışlardır. Bunun ardından Cenevizlilerin de Aydınoğulları'yla temasa geçip, Selçuk'ta 1351 yılında konsolusluk kurmaları, Selçuk’u, içinde tüccar bir İtalyan kolonisinin yaşadığı önemli bir ticaret merkezi haline getirmiştir. Venedikliler benzer bir ilişkiyi Menteşeoğulları Beyliği ile de kurmuşlar, taraflar arasında 1352 yılında imzalanan antlaşma ile çeşitli ticari ve diplomatik haklar elde etmişler, beyliğin merkezi olan Balat’ta bir konsolosluğa sahip olmuşlardır. İtalyan tacirler, aynı dönemde, Fethiye Körfezi'ndeki Fethiye limanından da çeşitli malları temin etmişlerdir. Türkler ve İtalyanlar arasında bu dönemde kurulan ticari ve siyasi ilişkiler sayesinde, farklı coğrafyalar arasında mal mübadelesi mümkün olmuş; Anadolu'dan alınan -aralarında Türk halılarının da olduğu- birçok nesne, Avrupa'nın değişik bölgelerine ulaştırılmıştır. 13. yüzyıl gibi erken bir dönemden itibaren, Anadolu'da üretilen bütün halı tipleri, Venedikli tüccarlar yoluyla, İtalya’ya ve öteki Avrupa ülkelerine ihraç edilmişlerdir. Bu mübadele ilişkisi, sanata da yansımış ve Türk halıları birçok İtalyan sanatçının resimlerinde yer almışlardır. ${ }^{44}$

Osmanlılar ve İtalyanlar arasındaki siyasi ve ekonomik ilişkiler de Osmanlıların erken dönemlerine tarihlenmektedir. Henüz Orhan Gazi döneminde, 1352 senesinden önce, Cenevizlilerle, onlara Osmanlı topraklarında ikamet etme hakkı veren ve çeşitli ticari imtiyazlar sağlayan bir antlaşma yapılmıştır. Osmanlı-Venedik arasındaki ticari ilişkiler de 1381 yılı gibi erken bir tarihte başlamıştır. Osmanlılar, Venedikliler ve Cenevizlilerin yanı sıra, Pisa, Floransa ve Napoli gibi İtalya'nın diğer bölgeleriyle de ticari bağlar kurmuşlardır. Özellikle Osmanlılar ve Venedikliler arasındaki siyasi, ticari ve diplomatik ilişkiler açısından, Fatih Sultan Mehmed dönemi (1451-1481) bir dönüm noktası olmuştur. Bu dönemde, Venediklilere İstanbul'da daimi bir elçi bulundurma hakkı ve ticari ayrıcalıklar verilmiş ve İtalyan sanatçılar, Fatih Sultan Mehmed'in himayesinde çalışmak üzere İstanbul'a davet edilmişlerdir. 14. yüzyılda bir ticaret antlaşmasıyla başlayan Türk-Venedik ilişkileri, çoğu zaman Akdeniz'deki egemenlik mücadelesi sebebiyle askeri ve siyasi olarak gergin bir hal alsa da, 18. yüzyılın ilk çeyreğine kadar kesintisiz bir şekilde devam etmiştir. Bu süreç boyunca devam eden insan ve eşya mübadelesi nedeniyle, sanat alanında da etkileşimler (örneğin Batılı ressamların bu dönemde Türk halılarını resimlerinde kullanmaları) olmuştur. ${ }^{45}$ Türkler ve İtalyanlar arasında yüzyıllar

44 Zeki Sönmez, Türk-İtalyan Siyaset ve Sanat İlişkileri, Bağlam Yayıncılık, İstanbul, 2006, s. 17-24.

45 Sönmez, a.g.e., s. 18-25. 
boyunca süren bütün bu ilişkiler göz önünde bulundurulduğunda, bunun sanat alanındaki bir yansımasının Lecce'deki Barok mimaride ortaya çıkma ihtimalinin ne kadar kuvvetli olduğu anlaşılabilir. Yukarıda da belirtildiği gibi, bu etkileşim doğrudan (Otranto Kuşatması yoluyla) ya da daha dolaylı olarak ticari yollardan, örneğin Osmanlılarla olduğu gibi aynı zamanda Lecce kentiyle de sıkı ticari ilişkilere sahip olan Venediklilerin, Osmanlı sanatının çeşitli örneklerini Lecce'ye getirmeleriyle gerçekleşmiş olabilir. San Giovanni Battista Kilisesi'nin cephesindeki şemse motiflerinin, bu etkileşim yoluyla Lecce'nin mimari diline dahil olmaları, güçlü bir olasılık olarak karşımıza çıkmaktadır.

Şemse motifi, halıların yanı sıra, 16. ve 17. yüzyıllarda üretilmiş olan Osmanlı kumaşlarında da, özellikle kemha (bir cins ipekli kumaş) olanlarda sıkça kullanılmıştır. ${ }^{46} \mathrm{Bu}$ dönemde Osmanlı Devleti, Avrupa'ya halıların dışında, kumaş da ihraç etmiştir. 16. yüzyılda Bursa'da üretilen kumaşların ününün Lehistan'a, Macaristan'a, Fransa'ya ve İtalya’ya kadar yayıldı̆̆ 1 belirtilmektedir. ${ }^{47}$ Osmanlıların Avrupa'ya kumaş tedarik ettiği, Venedik şehri dışında, Venedik Cumhuriyeti'ne ait olan başka bir toprakta, Dalmaçya'daki Split limanında da 17. yüzyılda tespit edilmiştir. Seyyah Evliyâ Çelebi (1611-1682) Split’te "Türkiye ile Venedik toprakları arasında ticaret konusu olan ipek, atlas ve brokar kumaşlarla, bezler, yün ve meşinlerle dolu 300 dükkân ya da ambar gördüğünü yazar." ${ }^{48}$ Dolayısıyla yine, Venedik’ten veya onunla bağlantılı Split gibi başka yerlerden, aralarında yoğun ticari bağlar olan Lecce'ye Türk kumaşlarının ulaşmış olması muhtemeldir. Aşağıda görülen (F.43) ve 16. yüzyıla tarihlenen Bursa işi kadife entarideki şemse motifi ile Lecce San Giovanni Battista Kilisesi'nin diş cephesindeki madalyon formunun (F.44) benzerliği bu olasılığg doğrular niteliktedir.

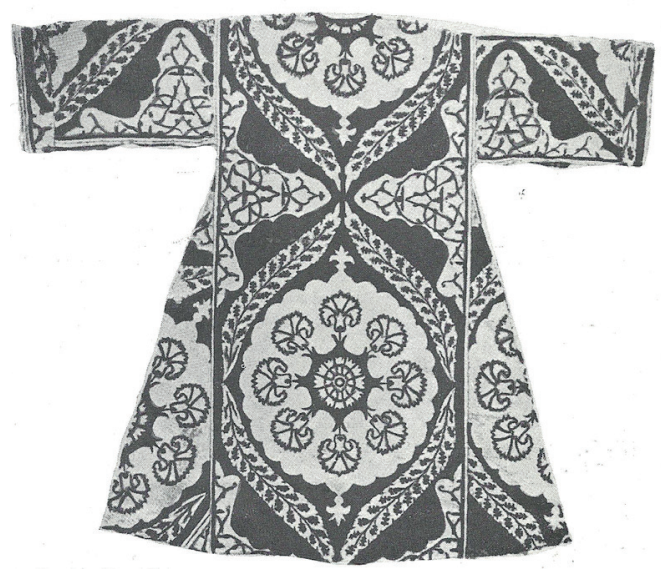

F. 43: Bursa işi kadife entari (16. yüzyı1) (Yatman, 1945, Resim No. 10)

46 Yasemin Güneş Akın, 16.-17. Yüzyıl Osmanı Kumaş, Halı ve Kilimlerinde Şemse Motifi, Marmara Üniversitesi, Güzel Sanatlar Enstitüsü, Yüksek Lisans Tezi, 2009, s. 32-33.

47 1567'de Leh Kralı'nın Bursa'dan 4000 filorilik kumaş satın aldığı Bursa mahkemei şer'iyye sicillerinde kayıtlıdır. Bkz. Nurettin Yatman, Türk Kumaşları, Ankara Halkevi Neşriyatı, Ankara, 1945, s. 14.

48 Valensi, a.g.e., s. 163. 


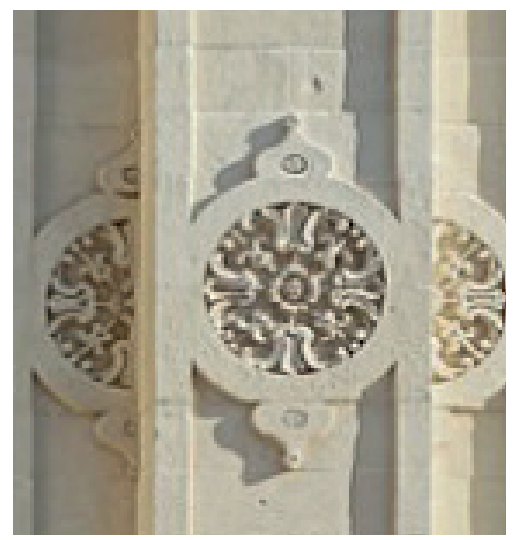

F. 44: Lecce, San Giovanni Battista Kilisesi (ayrıntı)

Kilisede bulunan madalyon motifinin başka bir muhtemel kaynağı, dönemin Osmanlı cilt sanatıdır. Osmanlı ciltlerinin klasik üslubunun şemseli cilt tipi olduğu belirtilmektedir. Bu ciltlerde, ortada şemse motifi bulunmaktadır. "Şemsenin alt ve üst tarafa doğru uzantılarına salbek denir. Kapağın dört köşesinde, üçgen biçiminde süsleme alanları, köşebent yer alır. Salbek, şemse ve köşebent kompozisyonunu zencirek ve cedvel çerçeveler." ${ }^{49}$ Zencirek ve cedvel, şemse ve köşebentlerden oluşan kompozisyonu çevreleyen süsleme kuşaklarıdır. Aşağıda, 17. yüzyıla ait bir cilt örneği görülmektedir (F.45). Buradaki salbekli şemse motifi, San Giovanni Battista Kilisesi'ndeki madalyon formunu hatırlatmaktadır. Şemsenin uzantılarının palmet şeklinde olması yine, mimar Giuseppe Zimbalo'nun tasarladığı yapılarda bu iki formun nasıl bir arada belirdiğine 1şık tutan bir açıklama olarak düşünülebilir. Türklere ait bir yazmanın, gerek savaş yoluyla (örneğin Otranto Kuşatması), gerekse ticaret yoluyla (Lecce'deki Venedikli tüccarlar) Lecce’ye ulaşmış ve böylelikle mimariyi etkilemiş olması ihtimal dahilindedir.

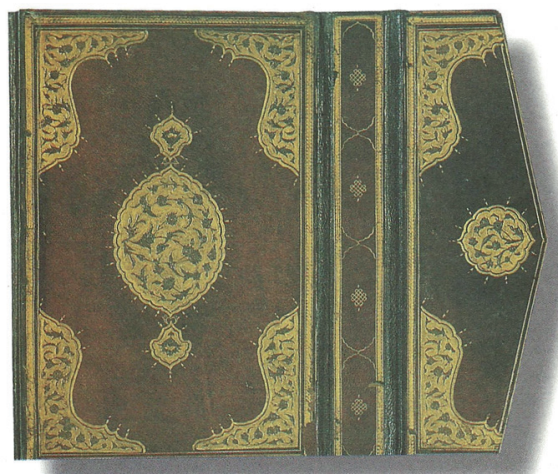

F. 45: Mevlâna, Mesnevî, cildin kapak içi, 17. yüzy1l, Süleymaniye Kütüphanesi Halet Efendi Koleksiyonu 174, 1029/1620 (Esiner Özen, 1998, Resim 19)

49 Mine Esiner Özen, Türk Cilt Sanatı, Türkiye İş Bankası Kültür Yayınları, Ankara, 1998, s. 14. 
Lecce'deki Barok üsluplu yapılarda görülen madalyon ve palmet motifleri, Türk minyatür sanatında tasvir edilmiş olan çeşitli formlarla da ilişkilendirilebilir. 17. yüzyıla (1600-1601) tarihlenen, Süleymaniye Kütüphanesi Halet Efendi Koleksiyonu 616 numarada bulunan ve 17. yüzyılın önemli devlet adamı Malkoç Ali Paşa'nın hayatını anlatan yazmanın minyatürleri, ${ }^{50}$ dönemin minyatürlerini anlamak için örnek olarak alınırsa, söz konusu motifler arasındaki benzerlik hemen fark edilebilir. Örneğin, San Giovanni Battista Kilisesi’nin cephesindeki yarım madalyon formu (F.47), yazmanın zahriye sayfasındaki tezhip düzeninde görülen yarım şemse motifi (F.46) ile paralellik taşımaktadır.

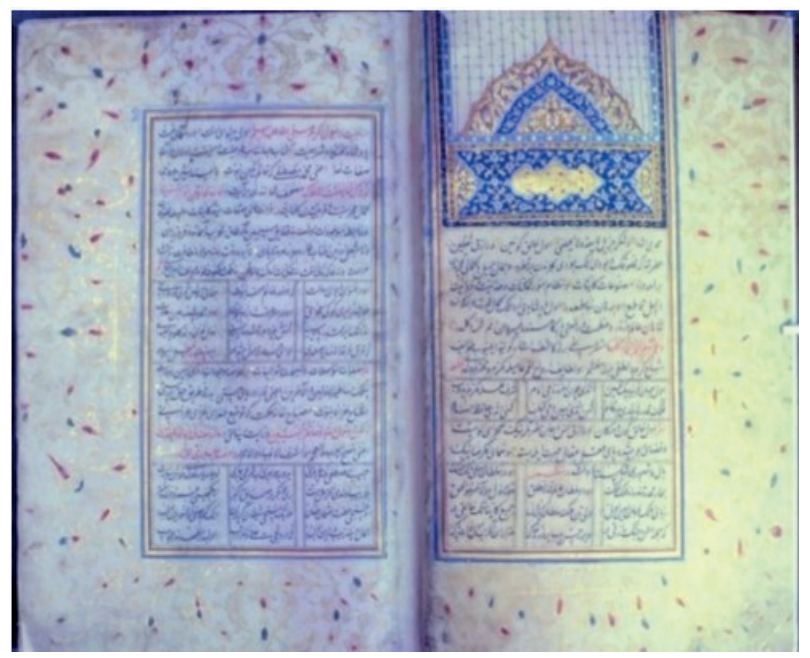

F. 46: Vekayi-i ‘Ali Paşa yazması, zahriye sayfası (Seçkin, 2007, s. 111)

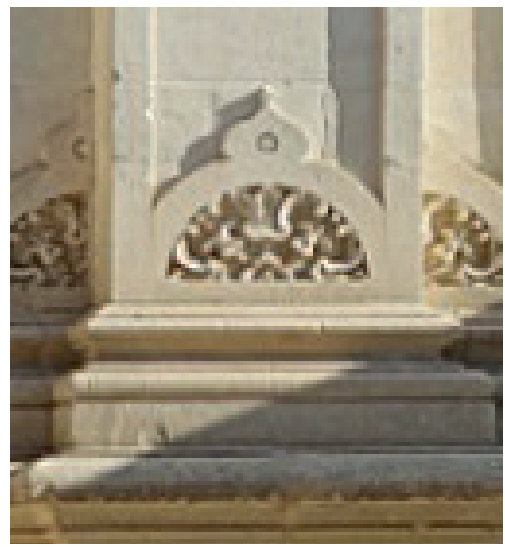

F. 47: Lecce, San Giovanni Battista Kilisesi, ayrınt1

50 Selçuk Seçkin, “17. Yüzyılın Önemli Minyatürlü Yazması Vekayi-i “Ali Paşa”, OTAM (Ankara Üniversitesi Osmanlı Tarihi Araştırma ve Uygulama Merkezi Dergisi), 2007, s. 95-96. 
Bu tezhip düzeninin dışında, yazmadaki “Kara Meydanında, Padişahın Emirleri Okuması” isimli minyatür (F.48) incelendiğinde, kilisenin cephesindeki formlarla, minyatürde tasvir edilen bazı motifler arasında benzerlik kurulabilir. Minyatürde, yüksek bir zemin üzerinde yan yana sıralanmış ve ellerini önünde kavuşturmuş vaziyette betimlenmiş olan figürlerin üzerinde, ortasında iri bir salbekli şemse motifi yer alan bir çetr (gölgelik) görülmektedir. Sayfanın üst kısmındaki bitiş bölümünde de bir palmet dizisi göze çarpmaktadır. ${ }^{51}$ Bu motiflerin, San Giovanni Battista Kilisesi'ndeki madalyon ve palmet formlarının esin kaynağı olmaları muhtemeldir.

Aynı yazmadan, “Malkoç Ali Paşa'nın İskenderiye'deki Otağı” isimli minyatürde (F.49), “[...] Paşanın, İskenderiye şehrine vardıktan sonra kendi otağını maiyetinin de daha geride kendi çadırlarını kurması ve daha sonra, otağın önündeki toplantı hali anlatılmıştır. Simetrik olarak düzenlenmiş olan kompozisyonda, ortada yüksekçe bir tahtın üzerinde Malkoç Ali Paşa, onun iki yanında birer saf olarak dizilmiş maiyeti yer almaktadır. [...] Otağın kapı bölümünün önünde, ipler yardımıyla tutturulmuş olan, sayeban (güneşlik) bulunur. Sayebanın üst bölümü salbekli şemseler ile süslenmiştir. Çadırın iki tarafında da aynı motif tekrarlanmıştır." 52 Ayrıca, hem Paşanın otağının, hem de arkada, maiyetinin çadırlarının tepe kısımlarının etrafı palmet dizisi ile çevrelenmiştir. Bu minyatür de, Osmanlı minyatür sanatının, Lecce'deki Barok üsluplu yapılara dahil edilen bazı motiflerin kaynağı olabileceğine işaret etmektedir.

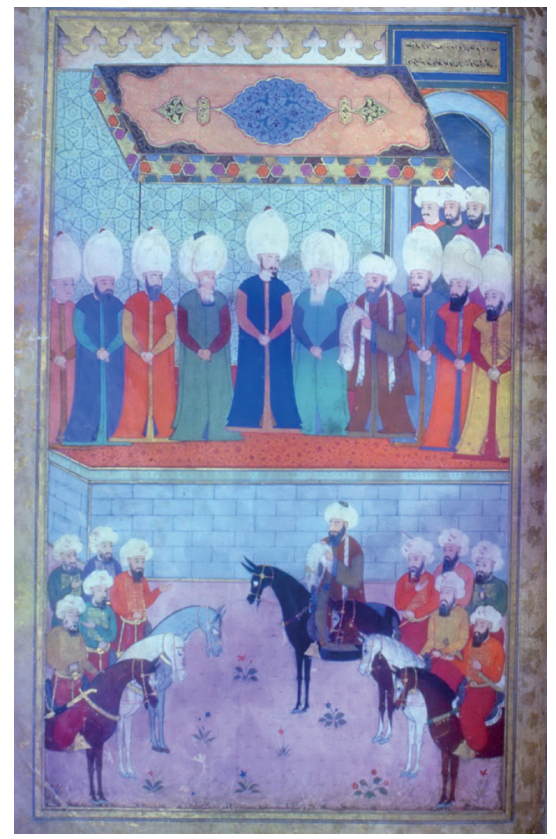

F. 48: Vekayi-i 'Ali Paşa yazması, Kara Meydanında, Padişahın Emirleri Okuması (Seçkin, 2007, s. 116)

51 Seçkin, a.g.e., s. 99.

52 Seçkin, a.g.e., s. 102. 


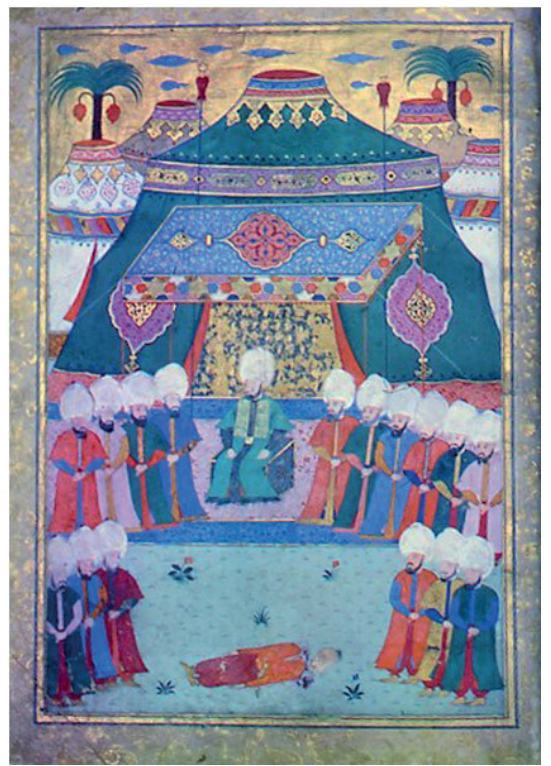

F. 49: Vekayi-i 'Ali Paşa yazması, Malkoç Ali Paşa'nın İskenderiye'deki Otağı (Seçkin, 2007, s. 120)

Şemse motifine, 16. ve 17. yüzyıllarda Türk maden sanatı örneklerinde de rastlanmaktadır. Dönemin teber, miğfer, zırh, kılıç gibi savaş aletlerinde de, günlük kullanım eşyalarında da şemse formu sıkça karşımıza çıkmaktadır. Aşağıda gösterilen demir malzemeden yapılmış Osmanlı teberi (F.50), 16. yüzyıl sonuna tarihlenmektedir. Teberin, ahşap sapa bağlanan demir gövdesinin üzerinde, gümüş kakma konturlu ve palmet şeklinde bir uzantıyla sonlanan dilimli yarım şemse formu yer almaktadır. Şemse, sülüs kitabeyle dolgulanmıştır. ${ }^{53} \mathrm{Bu}$ motif, San Giovanni Battista Kilisesi'ndeki, palmet şeklinde uzantıya sahip yarım şemse formları (F.51) ile bir arada düşünüldüğünde, aradaki benzerlik görülebilir.

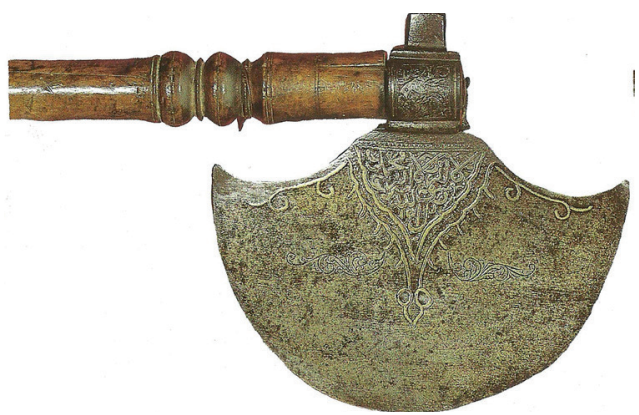

F. 50: Demir teber, Osmanl1, 16. yüzyıl sonu, Askeri Müze, 12988

(Bodur, 1987, s. 175)

53 Fulya Bodur, Türk Maden Sanatı, Türk Kültürüne Hizmet Vakfı Sanat Yayınları: 2, İstanbul, 1987, s. 175. 


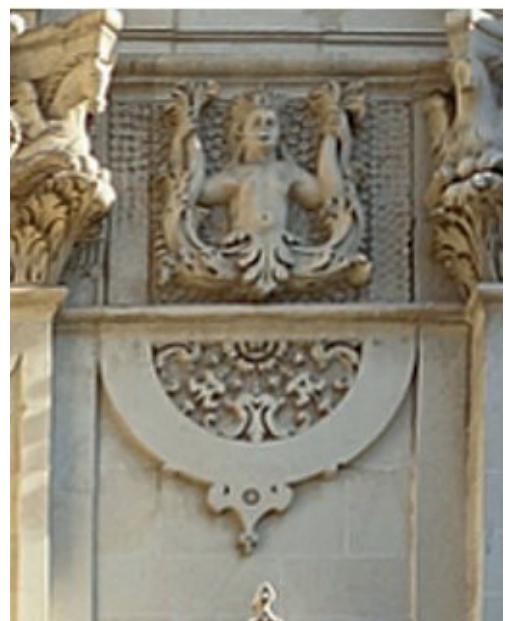

F. 51: Lecce, San Giovanni Battista Kilisesi (ayrınt1)

15.-17. yüzyıllar arasında kullanılan Türk miğferlerinde de şemse formu kullanılmıştır. Bu miğferlerde, "Belli süsleme programlarının tatbik edildiği eserlerin üzerinde Türk süsleme sanatına özgü bitkisel, geometrik, sembolik motifler gerek bordürler gerekse kapalı ve serbest kompozisyonlar halinde işlenmiştir." ${ }^{54}$ Aşağıda, şemse motifiyle bezenmiş bir Osmanlı miğferi görülmektedir (F.52).

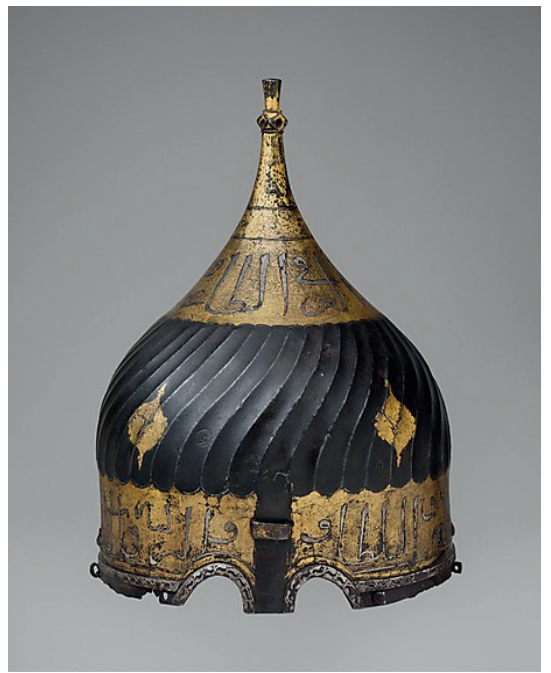

F. 52: Miğfer, Osmanl1, 15. yüzy1l, New York Metropolitan Museum of Art (https://tarihvearkeoloji.blogspot.com/2014/05/migfer-tul-ga.html, 06.12.2019)

54 Tülin Çoruhlu, "Miğfer", TDV İslam Ansiklopedisi, Cilt 30, İstanbul, 2005, s. 22. 
Benzer süsleme anlayışı, aynı dönemin at zırhlarına (F.53) ve kılıçlara da (F.54) yansımıştır. Ayrıca, maşrapa gibi günlük kullanım eşyalarında metal üzerinde (F.55) ya da Kur'an mahfazalarında, sedef kakma tekniğinin uygulandığı ahşap malzeme üzerinde (F.56), uzantıları olan tam ve yarım şemse motifleri görülebilir.

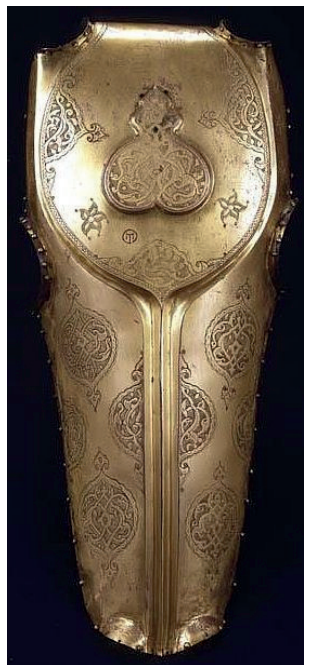

F. 53: At alın zirhı, Osmanlı 16. yüzyı1, Stibbert Müzesi, Floransa (https://www.pinterest.ch/pin/ $568368415447851769,06.12 .2019)$

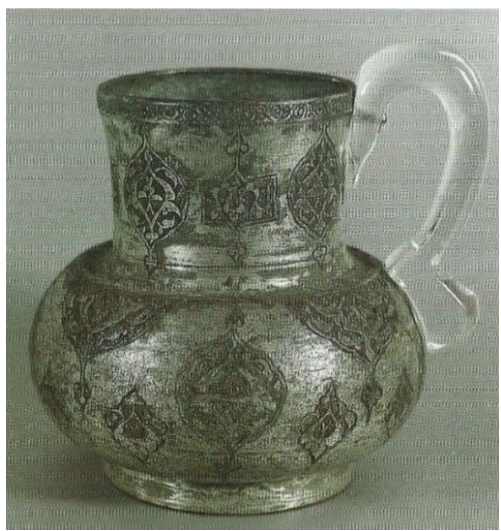

F. 55: Bakır maşrapa, Osmanlı, 16. yüzyıl ortası Sadberk Hanım Müzesi M.971-9111 (Bodur, 1987, s. 110)
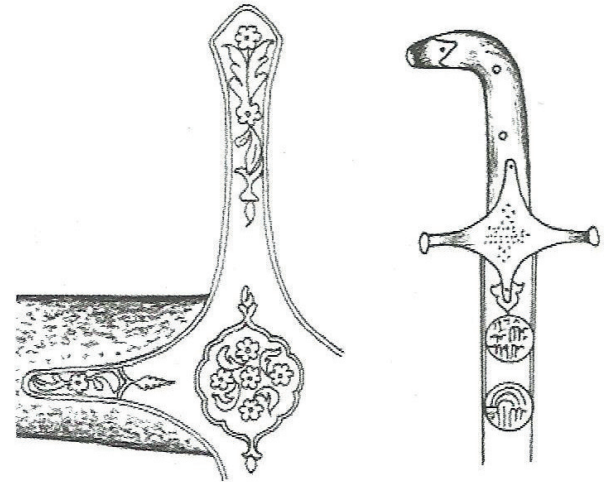

F. 54: Yavuz Sultan Selim ve Kanuni Sultan Süleyman'a ait kılıç, 16. yüzyıl (Tuluk, 2008, s. 121)

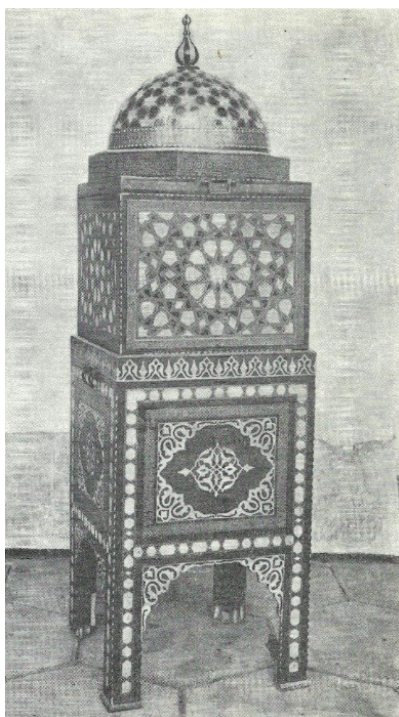

F. 56: Kur'an mahfazası, 17. yüzy11, Türk İslam Eserleri Müzesi (Züber, 1972, s. 108) 
Bütün bu örneklerde, Türk sanatında halı, kumaş, cilt, minyatür, metal ve ahşap üzerinde uygulanan şemse ve palmet gibi süsleme motiflerinin, Lecce'deki Barok üsluplu kiliselerin süsleme tasarımları için esin kaynağı olabileceği gösterilmiştir. Lecce kenti ve Osmanlı Devleti'nin arasında gerek savaş, gerekse de ticaret yoluyla oluşan etkileşim düşünüldüğünde, bu ihtimalin çok güçlü olduğu görülebilir. Ayrıca, Osmanlı sanatında 17. yüzyılda yoğun bir şekilde kullanılan motiflerin, tam da aynı dönemde Lecce'deki yapılarda ortaya çıkması, bu binaları tasarlayan mimar Giuseppe Zimbalo'nun, Türk sanatı örnekleriyle temas etmiş ve onlardan etkilenmiş olabileceğine işaret etmektedir.

Lecce'deki Barok üsluplu yapılarda tespit ettiğimiz ve Osmanlı sanatı etkisine işaret eden son mimari form Bursa kemeridir. "Üst kısmında yatay bir doğru ile bağlanan iki dörtte bir daireden meydana gelen ve fazla bir taşıma gücü olmadığı için daha çok süsleme işlerinde kullanılmış olan kemer" 55 olarak tanımlanan bu kemer formu, bir Katolik tarikatı olan Celestin'lerin yaptırmış olduğu Palazzo dei Celestini (F.57) isimli palazzo yapısında bulunmaktadır. Oldukça uzun ve iki katlı bir cepheye sahip olan yapının giriş katının inşaatına, 1659 yılında Matteo Napolitano'nun başrahipliği döneminde başlanmış; ikinci katın yapımı ise, 1688 yılında başrahip Girolamo Lasena'nın hamiliğinde başlamış ve 1695 'te tamamlanmıştır. ${ }^{56}$

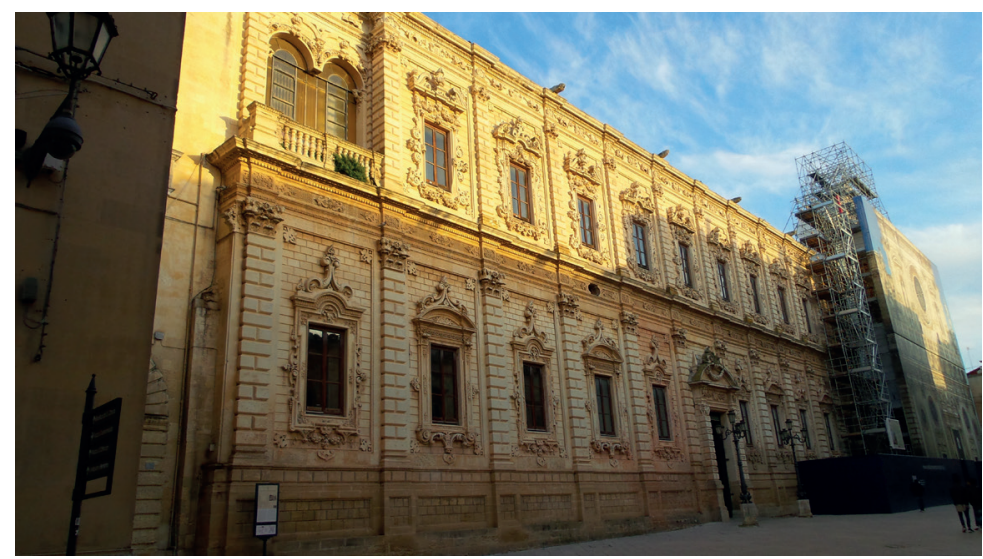

F. 57: Lecce, Palazzo dei Celestini

Mimar Giuseppe Cino’ya (1645-1722) atfedilen ikinci katta dikkati çeken bir nokta, katı soldan ve sağdan sınırlandıran bölümlerde simetrik olarak yer alan ikiz kemerli ve korkuluklu, loggia adı verilen balkon bölümleridir (F.58). Burada, yuvarlak formlu derin pencere kemerlerinin üzerinde, Batı mimarisinde fazla rastlanmayan bir tasarım olan iki Bursa kemeri görülmektedir (F.59).

55 Doğan Hasol, Ansiklopedik Mimarlık Sözlüğü, Yem Yayın, İstanbul, 2012, s. 251.

56 Michele Paone, Palazzi di Lecce, Congedo Editore, Lecce, 1978, s. 181. 


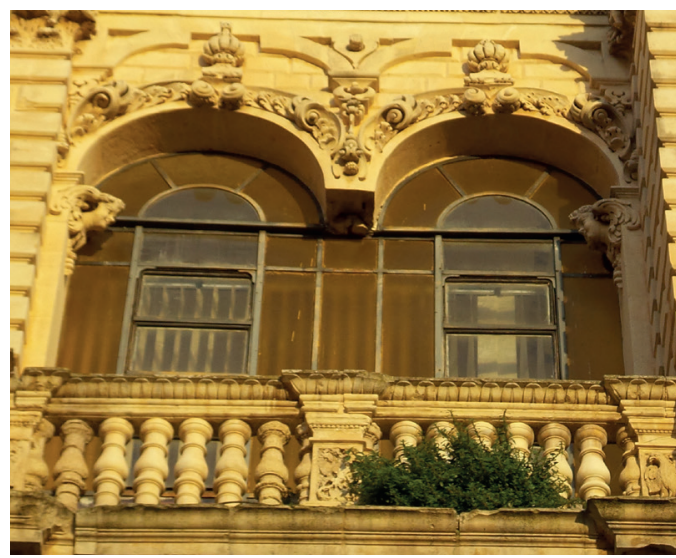

F. 58: Lecce, Palazzo dei Celestini, ikinci kat

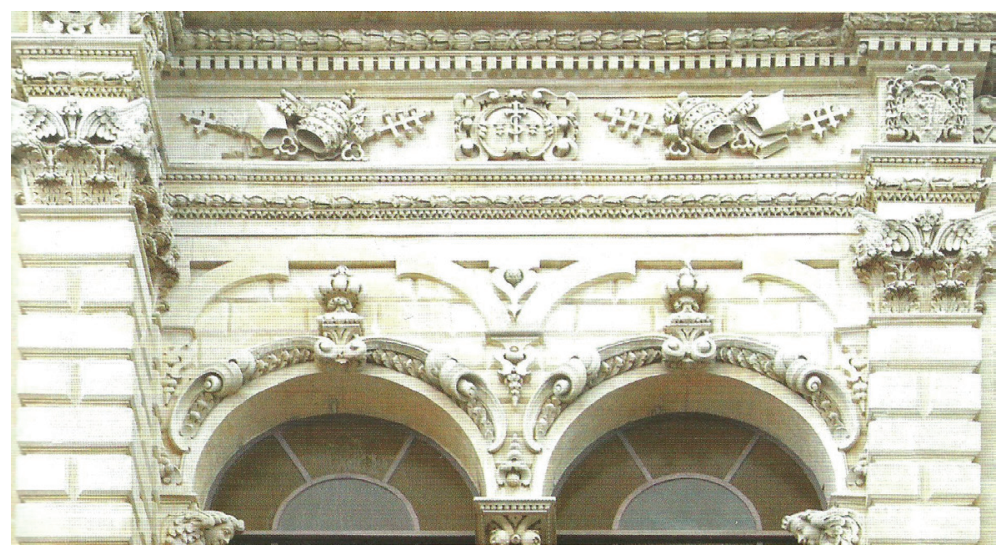

F. 59: Lecce, Palazzo dei Celestini, ikinci kat

Osmanlı sanatında, hem mimaride, hem de minyatürlerde sıkça kullanılan bu kemer tipinin, Lecce'de bir sarayda yer alması, şaşırtıcı bir nokta olarak karşımıza çıkmaktadır. Söz konusu kemerin Osmanlı mimarisinde kullanımının örneklerinden biri, Topkapı Sarayı'nda bulunan ve Mimar Sinan (1489-1588) tarafından 1578 tarihinde yapılmış olan III. Murad Köşkü’nün ${ }^{57}$ selsebilidir (F.60). Başka bir örnek ise, yine bir Mimar Sinan yapısı olan ve yapımı 1557'de tamamlanan Süleymaniye Camii'nin ${ }^{58}$ avlusunda bulunan şadırvandır (F.61).

57 Doğan Kuban, Osmanlı Mimarisi, Yem Yayın, İstanbul, 2007, s. 422.

58 Kuban, a.g.e., s. 279. 


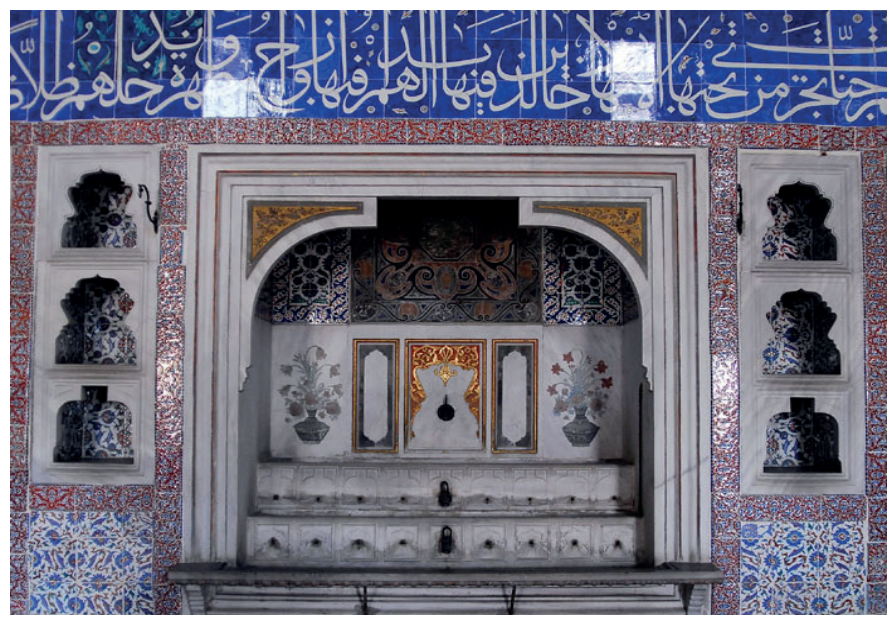

F. 60: Topkapı Sarayı, III. Murad Köşkü selsebili

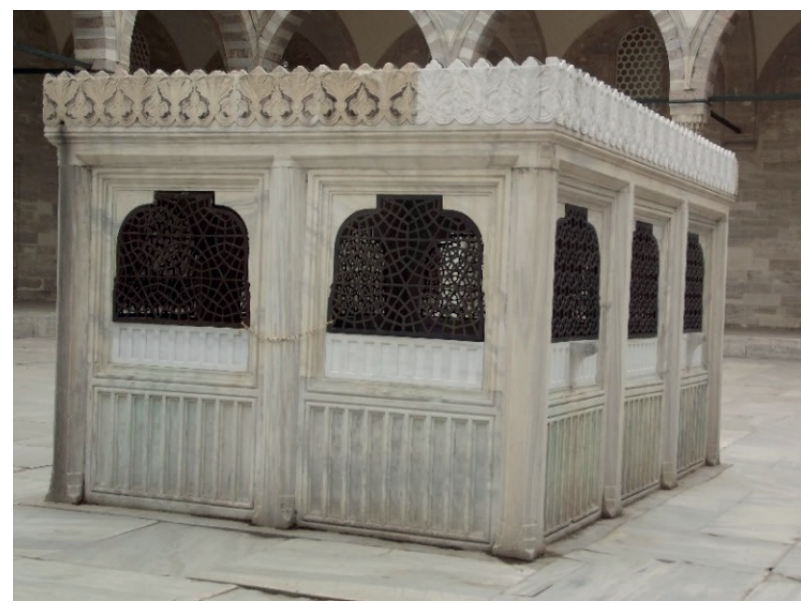

F. 61: Süleymaniye Camii avlusu, şadırvan

Bursa kemeri, Osmanlı minyatürlerinde de tasvir edilmiştir. Bunun bir örneği, şehnâmeci Seyyid Lokman (y. 1569-1596) tarafindan yazılan ve tasvirleri Nakkaş Osman tarafindan yapılan Klyâfetü'l-insâniye fì Şemâ'il ü'l-Osmaniye adlı eserdir. Osman Gazi'den III. Murad'a kadar olan Osmanlı padişahlarının portrelerini içeren bu eserde, bağdaş kurarak ya da diz çökerek oturur vaziyette betimlenmiş olan padişahların üzerinde, saltanat tahtını simgeleyen bir Bursa kemerli niş yer almaktadır (F.62). ${ }^{59}$ Yine Seyyid Lokman'ın, Osman Gazi'den Yavuz Sultan Selim'e kadar olan padişahların hünerlerini anlattığ ve 1588'de tamamlanan Hünername adlı eserinde, ${ }^{60}$ Kanuni Sultan Süleyman, bir Bursa kemeri altında tasvir edilmişstir (F.63).

59 Banu Mahir, Osmanlı Minyatür Sanatı, Kabalcı Yayıncılık, İstanbul, 2012, s. 62-63.

60 Mahir, a.g.e., s. 61-62. 


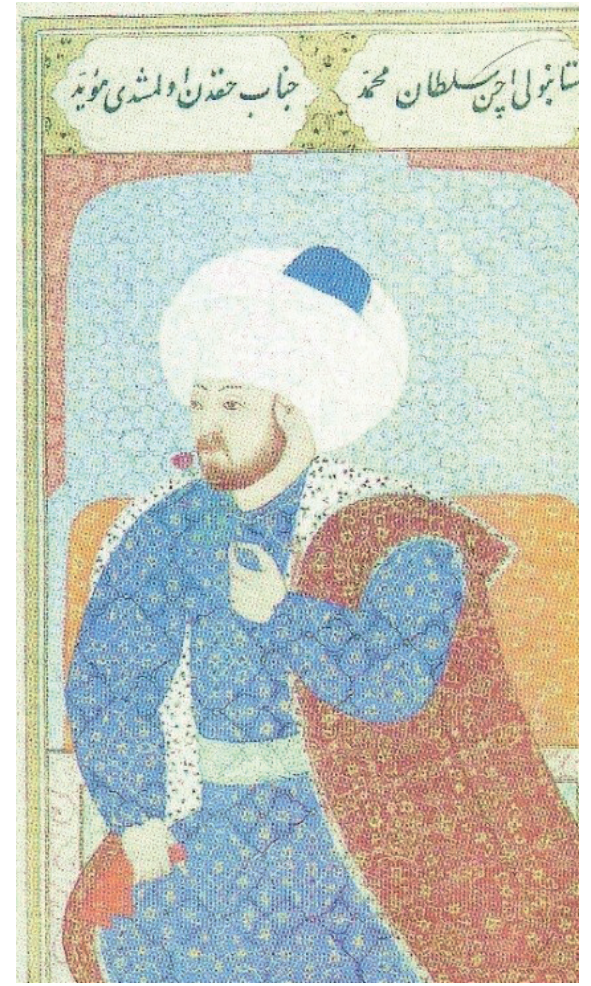

F. 62: Fatih Sultan Mehmed portresi, Kiyâfetü'l-insâniye fî Şemâ'il ü'lOsmaniye, Nakkaş Osman, 1579 (Mahir, 2012, Resim 21)

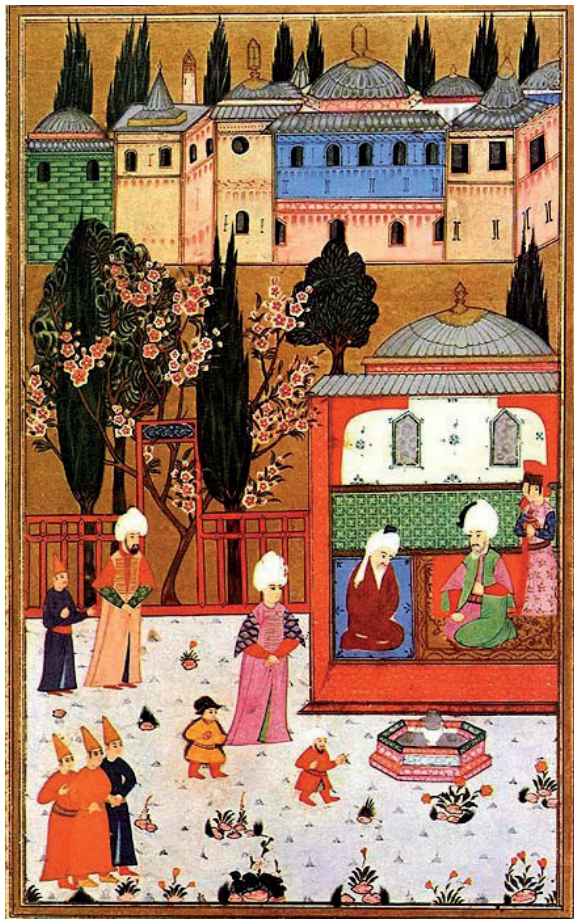

F. 63: Kanuni Sultan Süleyman'ın Şeyh Abdüllatif'i Kabulü, Hünernâme, 1588 (Konak, 2014, Foto: 22)

Birçok Osmanlı minyatüründe rastlanan Bursa kemeri formuyla, Lecce Palazzo dei Celestini'de kullanılan kemerler arasındaki paralellik, palazzodaki kemerin esin kaynağının, bir Osmanlı minyatürlü yazması olabileceğini düşündürmektedir. Lecce'de dini mimaride gözlemlenen, Osmanlı sanatı repertuarından alınma diğer motifler de göz önüne alındığında, bunun uzak bir ihtimal olmadığı anlaşılmaktadır. Lecce'ye çok yakın bir kasaba olan Nardò'da, 1710 yılında yenilenen ${ }^{61}$ Santa Chiara Manastırı'nda, pencerelerde ve bazı geçiş açıklıklarında kullanılmış olan kemer formu, bu olasılığı güçlendirmektedir (F.64).

61 Manieri Elia, a.g.e., Electa, Milano, 1996, s. 137. 


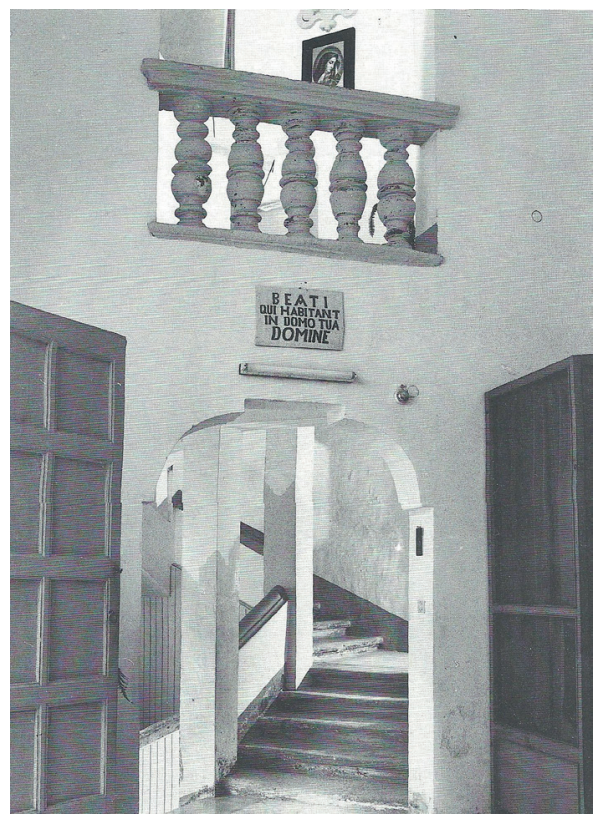

F. 64: Nardò, Santa Chiara Manastırı (Manieri Elia, 1996, s. 133)

\section{Sonuç ve Değerlendirme}

Bu çalışmada, İtalya'da bulunan Lecce kentinin Barok mimarisi üzerindeki olası Osmanlı sanatı etkilerine işaret edilmiştir. Lecce’ye gerçekleştirilmiş olan üç araştırma gezisi kapsamında bölgedeki Barok üsluplu dini ve sivil mimari örneklerinden topladığımız veriler ışığında, muhtelif yapılarda dikkatimizi çekmiş olan bazı süsleme motifleri ve mimari formlar, Türk sanatında bulunan bir takım öğelerle karşılaştırılmış ve aradaki şaşırtıcı benzerlik vurgulanmıştır.

Bu süsleme motiflerinden ilki, Lecce'deki Barok üsluplu 17. yüzyıl yapılarında sıkça rastlandığını tespit ettiğimiz ve Türk sanatındaki palmet motifine benzeyen bezeme öğesidir. Özellikle, söz konusu dönemde Lecce'de faal olan mimar Giuseppe Zimbalo tarafından yoğun bir şekilde uygulanan bu motifin, aynı dönemde Türk sanatında, çini, kumaş ve maden gibi çeşitli malzemeler üzerinde sıklıkla yer alması, Osmanlı ve İtalyan kültürleri arasında bir etkileşimi düşündürmektedir. İki kültür arasında 14. yüzyıldan başlayarak kesintisiz bir şekilde 18. yüzyıl başına kadar askeri, ticari, siyasi ve diplomatik yollarla devam eden ilişsiler göz önünde bulundurulduğunda, bunun güçlü bir ihtimal olduğu görülebilir. Söz konusu etkileşim, gerek askeri yollarla (örneğin Otranto Kuşatması sırasında, Türklere ait bir kumaş örneği veya sancak alemi gibi bir objenin Lecce'ye ulaşması), gerekse de ticari yollarla (hem Lecce hem de Osmanlı Devleti ile çok sıkı ticari ilişkilere sahip olan Venedik’ten Lecce'ye benzer bir nesnenin ulaşması gibi) gerçekleşmiş olabilir.

Lecce'deki Barok üsluplu 17. yüzyıl yapılarında saptadığımız ikinci form, yine aynı dönemdeki Türk sanatında çok çeşitli alanlarda karşımıza çıkan, iki yana uzantıları olan 
madalyon formu salbekli şemse motifidir. Lecce'de değişik yapılarda, özellikle yine mimar Giuseppe Zimbalo tarafından tasarlanan San Giovanni Battista Kilisesi'nde kullanılmış olan bu form, Türk sanatının halı, kumaş, cilt, minyatür, maden ve ahşap gibi alanlarındaki uygulamalarıyla karşılaştırılmış ve aradaki dikkat çekici benzerlik vurgulanmıştır. Bu bezeme öğesinin Lecce'nin süsleme repertuarına katılmasının, yine bir kültürel karşılaşma yoluyla, bir Türk sanatı örneğinin Lecce'li mimarların eline geçmesiyle gerçekleşmiş olabileceğine işaret edilmiştir.

Lecce'deki Barok mimari üzerindeki olası Osmanlı sanatı etkisi bağlamında tespit ettiğimiz üçüncü form ise, bir sivil mimari örneği olan, 17. yüzyıl yapısı Palazzo dei Celestini’de belirlediğimiz Bursa kemeri benzeri mimari öğedir. Osmanlı mimarisinde sıkça kullanılan bu kemer formuna, Lecce'deki bir palazzo yapısında rastlanılmış olması, yine bir kültürel etkileşimi gündeme getirmektedir. Bu formun, aynı dönemin Osmanlı minyatürlerinde sıklıkla kullanılmış olması, söz konusu öğenin, bir Osmanlı minyatürlü yazmasının Lecce’ye ulaşması yoluyla Lecce'nin mimari diline dahil olabileceği olasılığını akla getirmektedir.

Sonuç olarak, eğer bu yazıda işaret edilmiş olan olasılıklar doğruysa ve Lecce Barok mimarisi üzerinde Osmanlı sanatı etkileri varsa, bu, iki noktayı gündeme getirmektedir. Birincisi, Türklerin varlık göstermiş olduğu Güney İtalya bölgesinde, buna benzer başka kültürel etkileşim örnekleri var mıdır? Bu ilginç bir araştırma sorusu olarak karşımıza çıkmaktadır. Daha çok bir tespit niteliğinde olan ikinci nokta ise, sanatın her türlü çatışmanın sınırlarını aşan biricik doğasıdır; zira Lecce'li mimarlar, Osmanlı-İtalyan askeri gerilimine rağmen, Türk sanatından formları Lecce'deki yapılarda kullanmış olabilirler.

Hakem Değerlendirmesi: Dış bağımsız.

Çıkar Çatışması: Yazar çıkar çatışması bildirmemiştir.

Finansal Destek: Yazar bu çalışma için finansal destek almadığını beyan etmiştir.

Peer-review: Externally peer-reviewed.

Conflict of Interest: The author has no conflict of interest to declare.

Grant Support: The author declared that this study has received no financial support.

\section{Kaynakça/References}

Akın, Yasemin Güneş, 16.-17. Yüzyıl Osmanlı Kumaş, Halı ve Kilimlerinde Şemse Motifi, Marmara Üniversitesi Güzel Sanatlar Enstitüsü, Yüksek Lisans Tezi, 2009.

Arseven, Celâl Esad, Sanat Ansiklopedisi, Cilt IV, Milli Eğitim Basımevi, İstanbul, 1975.

Bodur, Fulya, Türk Maden Sanatı, Türk Kültürüne Hizmet Vakfi Sanat Yayınları: 2, İstanbul, 1987.

Calvesi, M., Manieri-Elia, M., Architettura Barocca a Lecce e in terra di Puglia, Carlo Bestetti Edizioni d'Arte, Roma, 1971.

Cantay, Gönül, “Türk Süsleme Sanatında Meyve”, Turkish Studies: International Periodical for the Languages, Literature and History of Turkish or Turkic, Cilt 3/5, Güz 2008, s. 32-64. 
Congedo, Fiorella, Guide to Lecce, Congedo Editore, Lecce, 1995.

Çoruhlu, Tülin, “Miğfer”, TDV İslam Ansiklopedisi, C.30, İstanbul, 2005, s. 21-23.

Dinçeli, Duygu, "Geleneksel Halı Sanatı İçerisinde Motiflerin İncelenmesi (Uşak Halıları)”, Akademik Sosyal Araştırmalar Dergisi, Y11: 7, Say1: 88, Şubat 2019, s. 546-563.

Esiner Özen, Mine, Türk Cilt Sanatı, Türkiye İş Bankası Kültür Yayınları, Ankara, 1998.

Fagiolo, M., Cazzato, V., La città nella storia d'Italia: Lecce, Editori Laterza, Bari, 1984.

Guida Artistica d'Italia, Arnoldo Mondadori Editore, Cilt 3, Milano, 1978.

Hess, Lawrence, "St. Francis of Paula", The Catholic Encyclopedia, C.6, Robert Appleton Company, New York, 1909, http://www.newadvent.org/cathen/06231a.htm, 5 Nisan 2019.

Konak, Ruhi, “Hünernâme II. Cilt Minyatürlerinde Kompozisyon Düzeni”, Ankara Üniversitesi Sosyal Bilimler Dergisi, 5 (2), s. 93-117.

Kuban, Doğan, Osmanlı Mimarisi, Yem Yayın, İstanbul, 2007.

Mahir, Banu, Osmanlı Minyatür Sanatı, Kabalcı Yayıncılı, İstanbul, 2012.

Manieri Elia, Mario, Barocco Leccese, Electa, Milano, 1996.

Öz, Tahsin, Türk Kumaş ve Kadifeleri, Cilt 2, Milli Eğitim Basımevi, İstanbul, 1951.

Michele Paone, Architetti in Lecce dal Rinascimento al Rococo, Edizioni Grifo, Lecce, 2010.

Paone, Michele, Chiese di Lecce, Cilt 1, Congedo Editore, Lecce, 1979.

Paone, Michele, Guida di Santa Croce, Congedo Editore, İtalya, 1994.

Paone, Michele, Lecce: Elegia del Barocca, Congedo Editore, Lecce, 1979.

Paone, Michele, Palazzi di Lecce, Congedo Editore, Lecce, 1978.

Pellegrino, Teodoro, Piazza Duomo a Lecce, Editoriale Adda, Bari, 1972.

Radino, Francesco, “La Puglia dalla civiltà messapica all’autonomia regionale”, Puglia, Touring Club Italiano, 1986.

Seçkin, Selçuk, “17. Yüzyılın Önemli Minyatürlü Yazması Vekayi-i ‘Ali Paşa”, OTAM (Ankara Üniversitesi Osmanlı Tarihi Araştırma ve Uygulama Merkezi Dergisi), 2007, s. 95-122.

Seward, D., Mountgarret, S., Old Puglia: A Cultural Companion to South-Eastern Italy, Haus Publishing, İspanya, 2016.

Sönmez, Zeki, Türk-İtalyan Siyaset ve Sanat İlişkileri, Bağlam Yayıncılık, İstanbul, 2006.

Sözen, M., Tanyeli, U., Sanat Kavram ve Terimleri Sözlüğü, Remzi Kitabevi, İstanbul, 2011.

Thoenes, C., Evers, B., Architectural Theory: From the Renaissance to the Present, Taschen, 2011.

Tuluk, Hasan, Türk Süsleme Sanatları İçinde Metal Sanatı, Milli Eğitim Bakanlığı Yayınları, Ankara, 2008.

Valensi, Lucette, Avrupa'da Müslümanlar (16.-18. Yüzyıllar), Çev. Alp Tümertekin, Türkiye İş Bankası Kültür Yayınları, İstanbul, 2015.

Vitruvius, Mimarlık Üzerine On Kitap, Çev. Suna Güven, Şevki Vanlı Mimarlık Vakfı Yayınları, 2013.

Watkin, David, A History of Western Architecture, Laurence King, Slovenya, 1996.

Yatman, Nurettin, Türk Kumaşları, Ankara Halkevi Neşriyatı, Ankara, 1945.

Yetkin, Şerare, Türk Halı Sanatı, Türkiye İş Bankası Kültür Yayınları, Ankara, 1991.

Züber, Hüsnü, Türk Süsleme Sanatı, Türkiye İş Bankası Kültür Yayınları, Ankara, 1972. 